\title{
Spatial and temporal variation in CO over Alberta using measurements from satellites, aircraft, and ground stations
}

\author{
H. S. Marey ${ }^{1,2}$, Z. Hashisho ${ }^{1}$, L. Fu ${ }^{3}$, and J. Gille ${ }^{4}$ \\ ${ }^{1}$ University of Alberta, Department of Civil and Environmental Engineering, Edmonton, Alberta, Canada \\ ${ }^{2}$ Alexandria University, Institute of Graduate Studies and Research, Alexandria, Egypt \\ ${ }^{3}$ Alberta Environment and Sustainable Resource Development, Environmental Monitoring, Alberta, Canada \\ ${ }^{4}$ National Center for Atmospheric Research, Boulder, Colorado, USA \\ Correspondence to: H. S. Marey (marey@ualberta.ca)
}

Received: 8 September 2014 - Published in Atmos. Chem. Phys. Discuss.: 16 December 2014

Revised: 13 February 2015 - Accepted: 16 March 2015 - Published: 14 April 2015

\begin{abstract}
Alberta is Canada's largest oil producer, and its oil sands deposits comprise $30 \%$ of the world's oil reserves. The process of bitumen extraction and upgrading releases trace gases and aerosols to the atmosphere. In this study we present satellite-based analysis to explore, for the first time, various contributing factors that affect tropospheric carbon monoxide (CO) levels over Alberta. The multispectral product that uses both near-infrared (NIR) and the thermalinfrared (TIR) radiances for CO retrieval from the Measurements of Pollution in the Troposphere (MOPITT) is examined for the 12-year period from 2002 to 2013. The Moderate Resolution Imaging Spectroradiometer (MODIS) thermal anomaly product from 2001 to 2013 is employed to investigate the seasonal and temporal variations in forest fires. Additionally, in situ $\mathrm{CO}$ measurements at industrial and urban sites are compared to satellite data. Furthermore, the available MOZAIC/IAGOS (Measurement of Ozone, Water Vapor, Carbon Monoxide, Nitrogen Oxide by Airbus In-Service Aircraft/In service Aircraft for Global Observing System) aircraft CO profiles (April 2009-December 2011) are used to validate MOPITT CO data. The climatological time curtain plot and spatial maps for $\mathrm{CO}$ over northern Alberta indicate the signatures of transported CO for two distinct biomass burning seasons: summer and spring. Distinct seasonal patterns of $\mathrm{CO}$ at the urban sites (Edmonton and Calgary) point to the strong influence of traffic. Meteorological parameters play an important role in the CO spatial distribution at various pressure levels. Northern Alberta shows a stronger upward lifting motion which leads to larger $\mathrm{CO}$ total column values, while the poor dispersion in central and southern $\mathrm{Al}-$
\end{abstract}

berta exacerbates the surface $\mathrm{CO}$ pollution. Interannual variations in satellite data depict a slightly decreasing trend for both regions, while the decline trend is more evident from ground observations, especially at the urban sites. MOPITT $\mathrm{CO}$ vertical averages and MOZAIC/IAGOS aircraft profiles were in good agreement within the standard deviations at all pressure levels. There is consistency between the time evolution of high-CO episodes monitored by satellite and ground measurements and the fire frequency peak time, which implies that biomass burning has affected the tropospheric $\mathrm{CO}$ distribution in northern Alberta. These findings have further demonstrated the potential use of the MOPITT V5 multispectral (NIR + TIR) product for assessing a complicated surface process.

\section{Introduction}

Canada's crude oil reserves represent the world's third largest after Saudi Arabia, and Canada is currently the world's sixth largest producer of crude oil (CAPP, 2012). Alberta is Canada's largest oil producer, and its oil sands deposits comprise $30 \%$ of the world's oil reserves (Kean, 2009). Alberta's oil sands deposits are located in three regions: Athabasca, Peace River, and Cold Lake. The Athabasca oil sands region (AOSR) (Fig. 1) contains most of the oil sands reserves. About $20 \%$ of the deposits in the Athabasca region are shallow ( $<75 \mathrm{~m}$ deep) and hence can be surface mined. The bitumen contained within the sand is extremely heavy crude oil, requiring heat or solvents to extract it from the sand (Alberta 
Environment, 2012). The surface mining of the bitumen utilizes a hot-water process for extraction, which releases $\mathrm{SO}_{2}$, $\mathrm{H}_{2} \mathrm{~S}$, and light hydrocarbons as well as $\mathrm{CO}_{2}$ and $\mathrm{CO}$ (Strausz et al., 1977). After extraction, water and solids are removed from bitumen using solvents/diluents such as naphtha (Siddique et al., 2007) and paraffins (Siddique et al., 2006), which are also used to decrease the bitumen's viscosity so that it can be ready for processing. Deeper deposits are not recoverable by surface mining: in situ recovery methods such as steam injection are needed for extraction. Large amounts of natural gas are required to upgrade the bitumen before it is sent through pipelines (NEB, 2015). Thus the rapid expansion of oil extraction, as well as massive energy requirements to extract and upgrade the bitumen, has led to numerous environmental concerns, particularly with regard to air quality (Timoney and Lee, 2009), and hence an environmental monitoring program that measures the ambient air quality is needed. Air monitoring in Alberta is carried out through airshed associations that were launched as non-profit societies under the umbrella of the Clean Air Strategic Alliance (CASA). Air quality in the AOSR is monitored locally by the Wood Buffalo Environmental Association (WBEA), which is a multi-stakeholder organization (WBEA, 2015). In addition to the existing continuous air quality monitoring network in Alberta, independent studies have been conducted to investigate the impact of the oil sands mining operations on the air quality over Alberta (e.g., Bytnerowicz et al., 2010; Jacob et al., 2010; Simpson et al., 2010; Howell et al., 2014). Recent studies of aerosol and trace gas emissions were carried out in summer 2008, when NASA DC-8 and P-3B research aircraft were deployed at the Canadian Forces Base Cold Lake in Alberta, Canada (Jacob et al., 2010). Simpson et al. (2010) analyzed these research aircraft data and they reported signi?cantly elevated levels of trace gases $\left(\mathrm{CO}_{2}, \mathrm{CH}_{4}\right.$, $\mathrm{CO}, \mathrm{NO}, \mathrm{NO}_{2}, \mathrm{NO}_{y}, \mathrm{SO}_{2}$, and $53 \mathrm{VOCs}$ ) above background levels. However, these data are limited in spatial coverage as they reflect local air quality and cannot provide information about the overall regional air quality. A complementary approach to surface and aircraft measurements is satellitebased monitoring, which can provide large spatial coverage and allow for making measurements over extended periods of time, allowing the study of the impact of intense emission sources on regional- and global-scale air quality. Over the last decade, satellite remote sensing of trace gases and aerosols for air quality applications has progressed (Martin, 2008). Despite the emerging importance of using satellite in air quality applications, there had been no studies published using them over Alberta until 2012, when McLinden et al. (2012) employed the Ozone Monitoring Instrument (OMI) instrument for $\mathrm{NO}_{2}$ and $\mathrm{SO}_{2}$ assessment over the AOSR. They presented high-resolution maps that revealed distinct increases above background levels for both species over the area of intensive surface mining. In addition, they showed that $\mathrm{NO}_{2}$ is increasing at a rate of $11 \%$ year $^{-1}$, which is generally consistent with the annual rate increase in bitu-

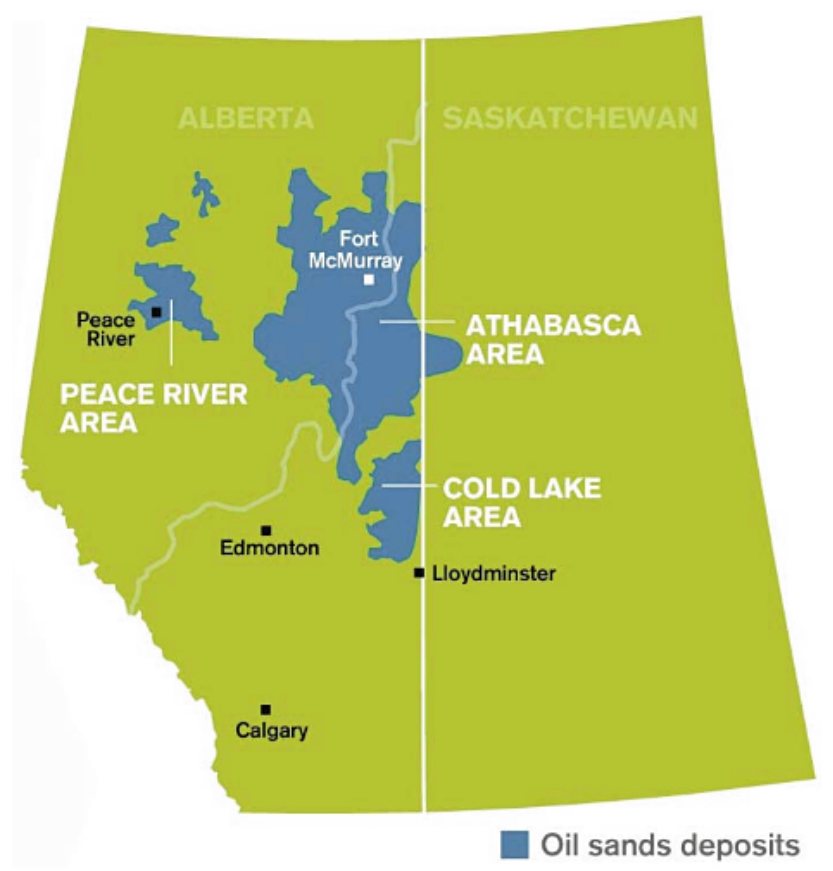

Figure 1. Alberta's oil sands deposits in the Athabasca, Peace River, and Cold Lake regions (http://www.energy.alberta.ca/oilsands/791. asp).

men production. Accordingly, further study to characterize more trace gases and aerosols that are emitted from various natural and anthropogenic sources in Alberta is required.

Beside oil sands operations, Alberta has other anthropogenic sources, such as combustion of fossil fuels and various industrial processes, which resulted in emissions $428692.5 \mathrm{t}$ of CO in 2012 (EC, 2012). Additionally, natural emissions such as boreal forest fires are a major source of CO. Canada boreal forest fires in summer influence the carbon cycle (Preston and Schmidt, 2006), climate (Amiro et al., 2001), and air quality (Colarco et al., 2004; Pfister et al., 2006). The fire frequency at high latitudes $\left(>55^{\circ} \mathrm{N}\right)$ is expected to increase (Gillett et al., 2004; Girardin, 2007) as a result of global warming (Stocks et al., 1998; Flannigan et al., 2005), which is accompanied by increased dryness and temperature (Marlon et al., 2008).

One of the most important trace gases emitted from anthropogenic pollution and open biomass burning is $\mathrm{CO}$. $\mathrm{CO}$ can also be produced from photochemical oxidation of $\mathrm{CH}_{4}$ and non-methane hydrocarbons (Novelli et al., 1998; Duncan et al., 2007). CO plays a critical role in tropospheric chemistry, where it is the dominant sink of the hydroxyl radical $(\mathrm{OH})$, which is the major oxidizing agent in the troposphere. It has also impacts on regional air quality, where it can be a precursor to photochemical ozone smog in areas with sufficient $\mathrm{NO}_{x}$ (Ridley et al., 1992). Additionally, $\mathrm{CO}$ was recognized as an important indirect greenhouse gas that could have an effect on global climate (Daniel and Solomon, 1998). 
With a relatively long lifetime (the global average CO lifetime is about 2 months), $\mathrm{CO}$ is an excellent tracer for tropospheric transport processes (Pétron et al., 2004) and plumes from strong emission sources that extend over great distances. Fortunately, $\mathrm{CO}$ is one of the few tropospheric gases that can be successfully monitored from space at the present time. It has been measured by the Measurements of Pollution in the Troposphere (MOPITT) instrument on NASA's Terra satellite, creating a global record from 2000 to the present. Thus, the long-term record of MOPITT data allows for the investigation of the interannual and spatial variability of tropospheric $\mathrm{CO}$ air quality. Accordingly the current study aims to address the general features of the overall $\mathrm{CO}$ loading over Alberta using MOPITT data. The major source contributions of $\mathrm{CO}$ and their impacts on temporal and spatial variability will be examined through the use of MOPITT and Moderate Resolution Imaging Spectroradiometer (MODIS) sensors, meteorology, and ground-level measurements. This work is the first study to explore various contributing factors that affect tropospheric CO levels over Alberta using satellite remote sensing observations. The data and methods used in the study are described briefly. Climatological spatial distribution and time-altitude profiles of MOPITT CO over Alberta are presented and compared with aircraft $\mathrm{CO}$ profiles and ground-level measurements. The contribution of forest fires to CO levels in the AOSR is analyzed using MODIS fire counts.

\section{Data and methods}

This study uses data from two satellite instruments: MODIS (available from https://earthdata.nasa.gov/data/ near-real-time-data/firms) and MOPITT V5J (available from ftp://15eil01.larc.nasa.gov/MOPITT/MOP02J.005) coupled with ground measurement data (available from http://www. casadata.org/). The areas of Fort McMurray, Edmonton, and Calgary are chosen for analysis, with the former representing an industrial oil sands region and the latter an urban region. The boundaries of the study areas are as follows Fort McMurray: $56.0-58.0^{\circ} \mathrm{N}, 112.0-110.0^{\circ} \mathrm{W}$; Edmonton: $52.0-54.0^{\circ} \mathrm{N}, 114.0-112.0^{\circ} \mathrm{W}$; and Calgary: $50.0-52.0^{\circ} \mathrm{N}$, $115.0-113.0^{\circ} \mathrm{W}$. Also, MOZAIC/IAGOS (Measurement of Ozone, Water Vapor, Carbon Monoxide, Nitrogen Oxide by Airbus In-Service Aircraft/In service Aircraft for Global Observing System) aircraft measurements are used for validation.

\subsection{Satellite data}

\subsubsection{MOPITT}

The MOPITT instrument onboard the Terra satellite is specifically designed to measure $\mathrm{CO}$ profiles and total columns (Drummond, 1992). It takes about 3 days for nearcomplete global coverage with a horizontal resolution of
$22 \mathrm{~km} \times 22 \mathrm{~km}$ at nadir (Deeter et al., 2003). MOPITT has a unique feature compared to other tropospheric $\mathrm{CO}$ satellite instruments, as it measures $\mathrm{CO}$ simultaneously in both the thermal-infrared (TIR) band $(4.7 \mu \mathrm{m})$ and the near-infrared (NIR) band $(2.3 \mu \mathrm{m})$. The NIR observations mainly provide information about the $\mathrm{CO}$ total column, whereas TIR radiances are often most sensitive to $\mathrm{CO}$ in the middle and upper troposphere. In this study we used the MOPITT multispectral product that exploits both channels (TIR + NIR), which has been shown to have higher sensitivity to $\mathrm{CO}$ in the lower troposphere (Worden et al., 2010; Deeter et al., 2011, 2012; Jiang et al., 2013). MOPITT V5 data have been recently validated using in situ $\mathrm{CO}$ profiles measured from aircraft (Deeter et al., 2013). Only daytime MOPITT retrievals were used in this study because the NIR channels operate using reflected sunlight, and so at night the TIR + NIR product is identical to the TIR product, which has no sensitivity near the surface.

\subsubsection{MODIS thermal anomaly products}

The MODIS sensors are located on the Terra and Aqua satellite platforms. They were designed to offer a broad range of information about land, oceanic, and atmospheric conditions (Kaufman et al., 1998a; Masuoka et al., 1998). They detect fires globally on a daily basis at $1 \mathrm{~km}$ spatial resolution. The fire detection algorithm has been described by Kaufman et al. (1998b) and Giglio et al. (2003). In this study we used the collection 5.1 Terra and Aqua MODIS MOD1/MYD14 product from November 2000 (Terra) and July 2002 (Aqua) through December 2012. Each fire pixel is associated with a confidence limit parameter to specify the quality of the data, which ranges from 0 to $100 \%$ (Giglio, 2010). The threshold limit for fire pixel confidence that is used in this study is $30 \%$, which is a heuristic measure of the radiometric contrast between a fire pixel and its immediate non-fire neighborhood, with extra penalties imposed near potential falsealarm sources such as cloud edges and coastlines (Giglio et al., 2003). We used the MODIS fire data in the shape file format in order to use them in geographic information system (GIS) maps. Data were obtained from the Land Atmosphere Near-real time Capability for EOS (LANCE) system operated by the NASA/GSFC/Earth Science Data.

\subsection{CASA ground measurements}

The CASA Data Warehouse (www.casadata.org) is a central repository for ambient air quality data collected in Alberta. The in situ measurements of surface $\mathrm{CO}$ were recorded at nine monitoring stations in the study region. $\mathrm{CO}$ is monitored continuously either by non-dispersive infrared photometry or gas filter correlation (www.casadata.org). The stations in Edmonton and Calgary are part of the monitoring network in typical urban centers; however the Fort McMurray station represents an industrial region. 


\subsection{MOZAIC/IAGOS}

The IAGOS (formerly MOZAIC) instruments, which have been onboard commercial aircraft since August 1994, aim to sample the tropospheric gases with high vertical resolution over about 50 airports (Marenco et al., 1998). CO has been monitored since 2001 using the infrared CO analyzer (model 48CTL from Thermo Environmental Instruments, USA) with a precision of \pm 5 ppbv (Nedelec et al., 2003). Data are available at http://www.iagos.org.

\subsection{Meteorological data and HYSPLIT trajectories}

The HYSPLIT (Hybrid Single-Particle Lagrangian Integrated Trajectory) model version 4 was used to generate air mass backward trajectories. It is the latest version of an integrated system for computing air parcel trajectories, dispersion, and deposition simulations. The model calculates the trajectories using the Global Data Assimilation System (GDAS) meteorological data set, which is operated by the National Centers for Environmental Prediction (NCEP) (Rolph, 2015; Draxler and Rolph, 2015). Trajectory calculation is carried out via time integration of the position of an air parcel as it is transported by the 3-D winds (Draxler and Hess, 1998). Data of mean monthly omega for the study period were taken from the National Oceanic and Atmospheric Administration (NOAA) Climate Data Assimilation System I, based on the National Centers for Environmental Prediction/National Center for Atmospheric Research (NCEP/NCAR) Reanalysis Project. The NCEP/NCAR global reanalysis meteorological data set is described in detail by Kalnay et al. (1996).

\section{Results and discussion}

\subsection{Climatological spatial distribution of MOPITT CO over Alberta}

Figure 2 shows the seasonally averaged distribution of MOPITT CO total column measurements over Alberta for the period March 2002 to December 2013. The symbols F, E, and $\mathrm{C}$ represent the cities of Fort McMurray, Edmonton, and Calgary, respectively. Data are gridded at $0.25 \times 0.25^{\circ}$ resolution. Figure 2 depicts the seasonal climatological maps for $\mathrm{CO}$ total columns. High $\mathrm{CO}$ loadings extended from the northeast to northwest of Alberta in all seasons except fall (September-November), as its spatial variations are less prominent (the flattest distribution). CO total columns illustrate remarkable maximum values in the northeastern area (oil sands area) in the spring (March-May), when the CO total column ranges are $2.5-2.75 \times 10^{18}$ molecules $\mathrm{cm}^{-2}$. Additionally, it is apparent that the summer (June-August) and fall (September-November) seasons display minimum CO loading, especially in central and southern Alberta.
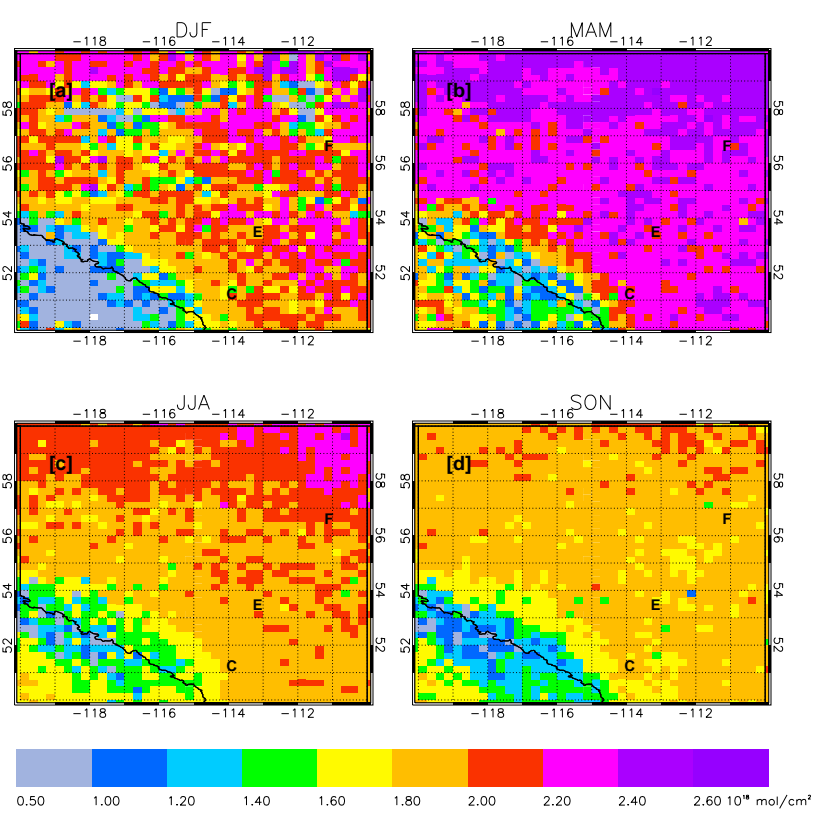

Figure 2. The MOPITT daytime CO total column measurements over Alberta for the period March 2002 to December 2013 in (a) winter, (b) spring, (c) summer, and (d) fall. The symbols F, E, and $\mathrm{C}$ represent the cities of Fort McMurray, Edmonton, and Calgary, respectively. Data are gridded at $0.25 \times 0.25^{\circ}$ resolution.

The spatial distributions of $\mathrm{CO}$ mixing ratios at the surface level (Fig. 3) reveal distinct enhancements, covering southeastern Alberta in winter with $\mathrm{CO}$ mixing ratios of 180-200 ppb. In the spring the CO mixing ratios are generally high in the whole of Alberta. The summer season demonstrates relatively high surface $\mathrm{CO}$ concentrations (140-160 ppb) north of Fort McMurray, although it shows minimum levels for the rest of Alberta, while the fall season illustrates distinctly flatter spatial distribution. Thus, the spatial distributions of surface $\mathrm{CO}$, especially in spring, indicate a different pattern than the CO total column (Fig. 2) for the same period. To assist in the interpretation of the results, the vertical velocity (omega), which is defined as change in pressure with time, is analyzed. The spatial distributions of averaged omega $(\mathrm{d} p / \mathrm{d} t)$ for 2002-2013 at pressure level $850 \mathrm{mb}$ for four seasons are depicted in Fig. 4. These distributions demonstrate upward movements of air mass in the area of northeastern and southwestern Alberta as indicated by negative values. This suggests that the $\mathrm{CO}$ emissions are uplifted, raising the $\mathrm{CO}$ total column values in the northern area. Conversely, downward movements (positive values) are recorded in central and southeastern Alberta, allowing subsidence of $\mathrm{CO}$ emissions as conditions are favorable. Therefore, there is general consistency between the climatological maps of omega and the CO spatial distributions, as the CO total columns show remarkable enhancements in the north, while the surface $\mathrm{CO}$ experiences elevated values in 

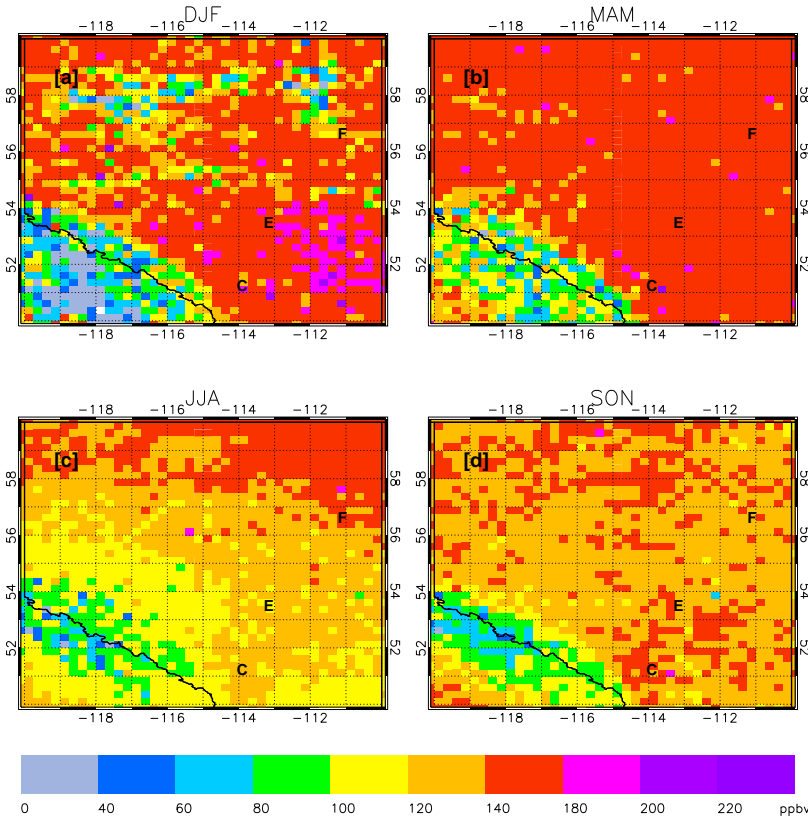

Figure 3. MOPITT daytime CO mixing ratios at the surface level over Alberta for the period March 2002 to December 2013 in (a) winter, (b) spring, (c) summer, and (d) fall. The symbols F, E, and $\mathrm{C}$ represent the cities of Fort McMurray, Edmonton, and Calgary, respectively. Data are gridded at $0.25 \times 0.25^{\circ}$ resolution.

the southern area. This highlights the important role of meteorological parameters on ambient air quality.

The southwestern area of Alberta exhibits minimum $\mathrm{CO}$ levels, which are less than $1.5 \times 10^{18}$ molecule $\mathrm{cm}^{-2}$ and $60 \mathrm{ppb}$ for $\mathrm{CO}$ total column and surface concentration (Figs. 2 and 3), respectively. Alberta has a varied topography, from mountain peaks along the western border to lowland areas in northeastern Alberta. It follows, then, that topographical features influence air quality - mountainous regions with low populations contribute to background conditions of $\mathrm{CO}$ resulting in the lowest $\mathrm{CO}$ concentrations in southwestern Alberta.

The main sources of $\mathrm{CO}$ in the atmosphere are incomplete combustion processes and photochemical oxidation of hydrocarbons (Novelli et al., 1998; Duncan et al., 2007). Hence, it is assumed that $\mathrm{CO}$ spatial variations in northern Alberta are associated with oil sands industrial activities and forest fires (will be discussed in Sect. 3.5). It is reported that oil sands industry consumption of natural gas is 21 million $\mathrm{m}^{3}$ day $^{-1}$ in 2003 and is expected to increase to 60 million $\mathrm{m}^{3}$ day $^{-1}$ in 2015 (NEB, 2015). However with increasing regulation of the combustion, $\mathrm{CO}$ is expected to decrease.

The extracted bitumen is then upgraded in upgraders located north of Fort McMurray as well as downstream industrial centers such as the industrial heartland in Fort Saskatchewan (northeastern Edmonton), Alberta. A small
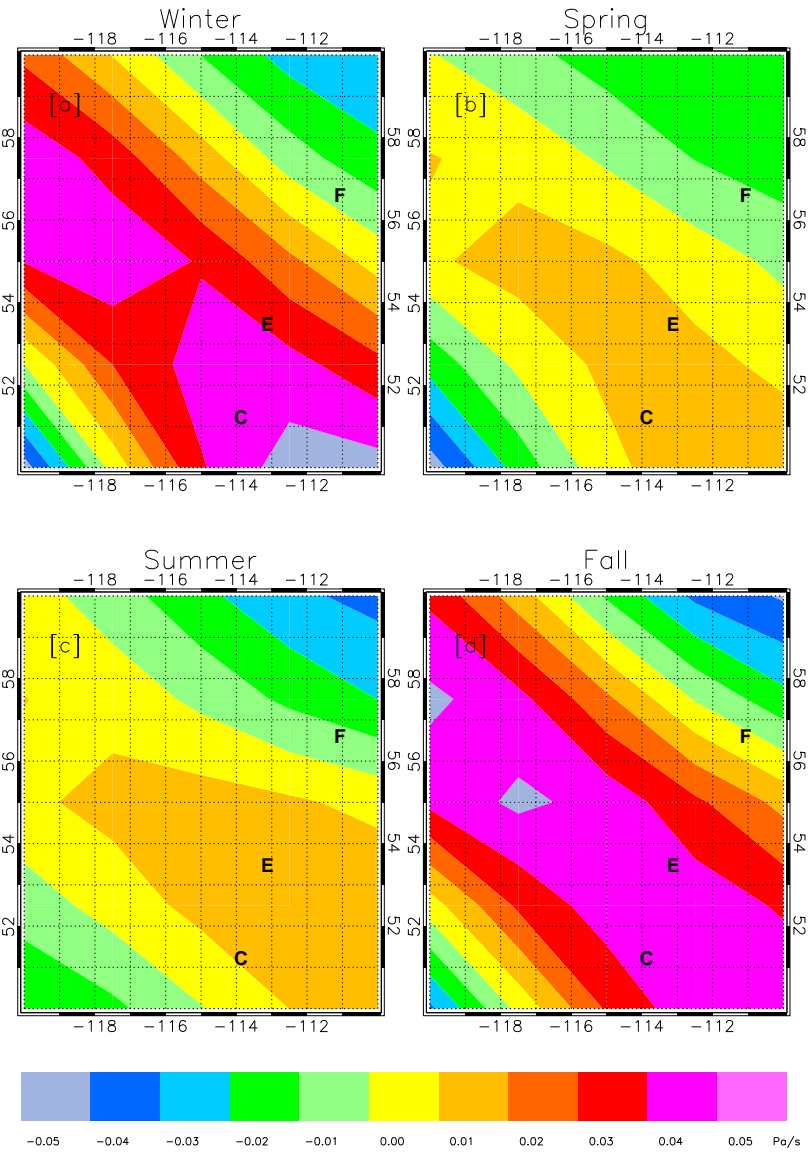

Figure 4. Spatial distributions of omega at pressure level $850 \mathrm{mb}$ for the period from 2002 to 2013 in winter (a), spring (b), summer (c), and fall (d).

fraction of diluent used in bitumen extraction and transport is emitted to the atmosphere (Siddique et al., 2006). The diluents are mainly aromatic and aliphatic hydrocarbons (Siddique et al., 2007). As reported in earlier studies, the measured CO on 10 July 2008, as part of Arctic Research of the Composition of the Troposphere from Aircraft and Satellites (ARCTAS) mission showed a strong correlation with alkanes, aromatics, and cycloalkanes, which are associated with direct emissions from the oil sands and/or diluent (Simpson et al., 2010). Furthermore, the timing, distribution of other sporadic sources such as fires, and the effects of large-scale transport have a substantial influence on the spatial discrepancies.

\subsection{Time-altitude MOPITT CO}

To gain further insight about the impact of various emission sources on $\mathrm{CO}$ levels, temporal climatologies of 12 years for the Fort McMurray (including the oil sands area), Edmonton, and Calgary areas are calculated. The monthly mean CO profiles using all the available MOPITT data between March 2002 and December 2013 are used for altitude/month 
contours for the two regions (Fig. 5). The vertical profiles of MOPITT CO are retrieved on only 10 altitude levels (surface, $900,800,700,600,500,400,300,200,100 \mathrm{hPa}$ ), so levels in between have been linearly interpolated. However, earlier studies of averaging kernels (a measure of sensitivity) have indicated that there are effectively no more than two independent pieces of information (1.4-2) in the vertical profiles retrieved by MOPITT, with more sensitivity to the middle troposphere (Deeter et al., 2007; Worden et al., 2010).

Generally, all regions demonstrate the same profile structure where $\mathrm{CO}$ mixing ratios are higher at low altitudes (high pressure) than high altitudes (low pressure). At Edmonton and Calgary, the vertical CO profile exhibits significant elevated levels in winter and spring, occurring in February and April with maximum mixing ratios of $175 \mathrm{ppb}$ at low altitude levels $(\leq 800 \mathrm{hPa})$, while it shows minimum mixing ratios in summer. This pattern is consistent with the general seasonal cycle of $\mathrm{CO}$ in the Northern Hemisphere (NH). Edwards et al. (2004) analyzed CO variability from the Terra MOPITT satellite in the $\mathrm{NH}$, and their result showed peak values in the early spring due to fossil fuel burning for heating and increased power requirements. The wintertime $\mathrm{CO}$ emissions persist for several weeks after the emissions themselves have ceased, causing high $\mathrm{CO}$ concentrations to be detected in early spring. In fact, the seasonal cycle of $\mathrm{CO}$ loading is driven primarily by the balance of emissions and photochemical production, as well as destruction by the hydroxyl radical (OH) (Novelli et al., 1998). During the summer months, under conditions of high solar illumination, $\mathrm{OH}$ is produced mainly through $\mathrm{O}_{3}$ photolysis and subsequent reaction with $\mathrm{H}_{2} \mathrm{O}$, which accounts for strongest sink of $\mathrm{CO}$ in summer. Thus the main ( $90 \%$ ) $\mathrm{CO}$ loss is caused by $\mathrm{OH}$ oxidation, followed by dry deposition (Thompson, 1992).

Although both Calgary and Edmonton represent urban pollution, Calgary CO concentrations show lower values in winter. Different air masses and weather systems influence Alberta, and it is likely that these have a significant impact on air quality. Southwestern Alberta indicates a complex and non-uniform spatial pattern of chinook frequency in winter that is associated with a warmer temperature anomaly and strong westerly winds. In particular, Calgary is expected to experience chinook winds more than Edmonton since chinook effects are strongest in southern portions of Alberta. Accordingly, Calgary is more affected by westerly winds that carry fresh air from the mountains, which may contribute to pollution dilution (Cullen and Marshall, 2011).

The seasonality in the Fort McMurray area has two peaks, as there is a marked increase in CO loading in summer (looks more like April and May), especially at low altitude levels $(\leq 800 \mathrm{hPa})$. However, because the $\mathrm{OH}$ loading is higher in summer than spring, the $\mathrm{CO}$ peak does not persist long and declines rapidly. Simpson et al. (2011) calculated backward trajectories for 10 days starting on 10 July 2008 over the Athabasca surface mines (northeastern Alberta) as part of the summer deployment of the ARCTAS field mission. The
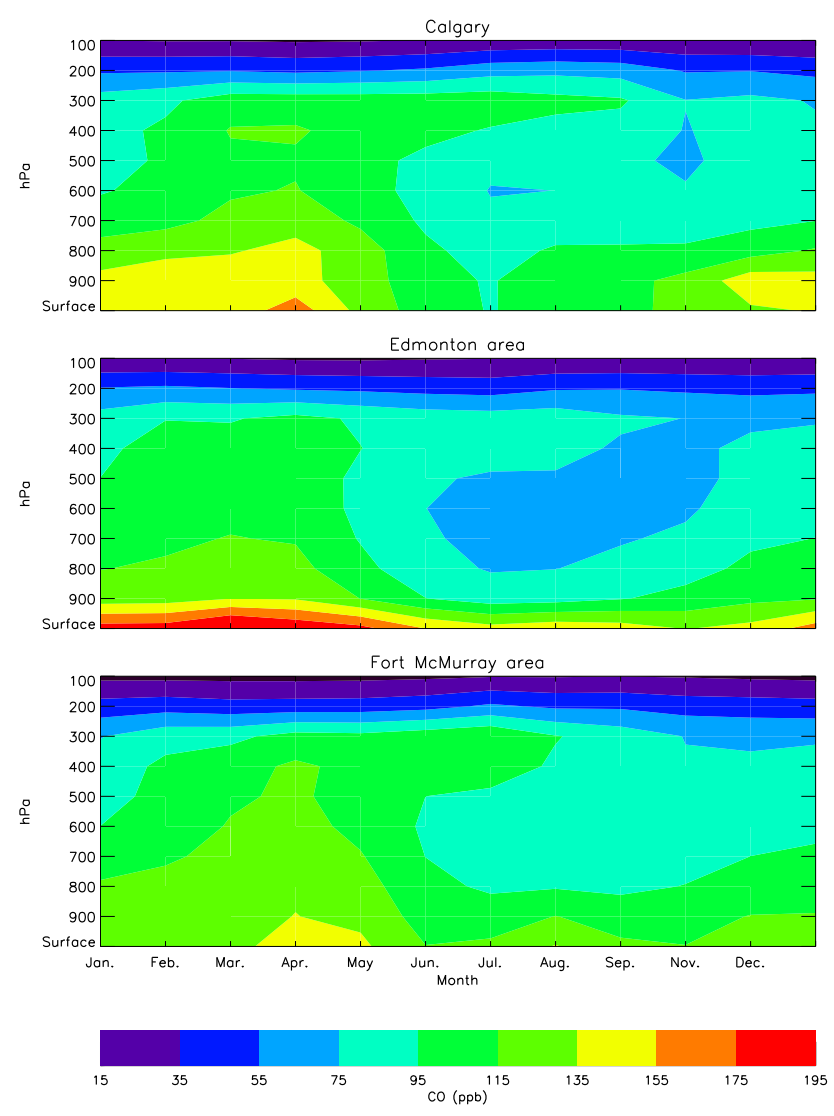

Figure 5. Climatological MOPITT CO profiles for the period March 2002 to December 2013 over the Calgary, Edmonton, and Fort McMurray areas.

aircraft flew over both boreal forest and industrial land, including tailings ponds and upgrader facilities. Then the aircraft flew to a clean air area further south of the oil sands area. The 10-day backward trajectories for the area south of the oil sands (by $1^{\circ}$ ) and clean areas revealed that the air masses are transported to the aircraft's pressure level from the west and not from oil sands mines to the north. Consequently, summer $\mathrm{CO}$ increments can be attributed to other sporadic sources such as forest fires. The forest fire emissions will be discussed in Sect. 3.5. Furthermore the winter/spring levels over the Fort McMurray area start to peak late in April and May, with maximum mixing ratios of 135$155 \mathrm{ppb}(\leq 800 \mathrm{hPa})$. Figure 5 illustrates higher $\mathrm{CO}$ mixing ratios at low altitude levels $(\leq 800 \mathrm{hPa})$ over the Edmonton and Calgary areas than the Fort McMurray area, especially in winter and spring, which points out the significance of the non-industrial sources (e.g., vehicle emissions) . It is reported that $\mathrm{CO}$ emissions from mobile sources (e.g., transportation emissions) over Alberta in 2011 were about $900000 \mathrm{t}$, which is about $60 \%$ of the total CO emissions (1.5 Mt) (EC, 2012).

For all locations, CO mixing ratios in spring exhibit greater values at higher altitudes (pressures less than 


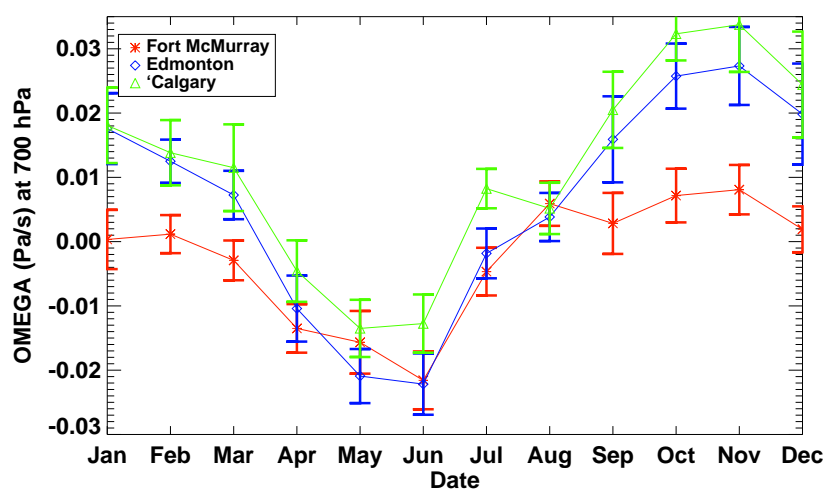

Figure 6. Omega averages at $700 \mathrm{hPa}$ from 2002 to 2013.

$700 \mathrm{hPa}$ ) compared to other seasons. This could be attributed to seasonal variations in vertical motion or mixing, which lofts surface emissions into the upper troposphere (e.g., Duncan et al., 2007; Jiang et al., 2007; Liu et al., 2010; Livesey et al., 2013). This is further confirmed by monthly omega averages (2002-2013) at $700 \mathrm{hPa}$ (Fig. 6), which indicate that the vertical mixing is more usual in May and June, when omega averages range from -0.02 to -0.01 .

Although monthly $\mathrm{CO}$ mixing ratios over the Edmonton and Calgary areas are higher at lower altitudes, the $\mathrm{CO}$ total column monthly averages for all regions are comparable (not shown). This indicates that northern Alberta is affected more by $\mathrm{CO}$ plumes transported vertically above the planetary boundary layer (PBL), whereas cities such as Edmonton and Calgary are more influenced by local emissions confined in the PBL, which is more pronounced over the Edmonton area.

Figure 7 shows the 12-year time series of monthly averaged $\mathrm{CO}$ mixing ratios (ppb) as measured by MOPITT from January 2002 to December 2013 at the 10 pressure levels over the Fort McMurray, Edmonton, and Calgary areas. The white intervals indicate missing data due to calibration events or instrument problems or that the pressure at that location is less than the MOPITT pressure level.

Strong seasonal cycles are seen over all regions through all the years, with maximum values in springtime. The magnitude of seasonal variability is not the same for all years and regions: it is more pronounced over the Edmonton and Calgary areas. CO mixing ratios show a sharp vertical gradient especially over the Edmonton and Calgary areas, with significantly higher values in the PBL than in the free troposphere (FT). This implies that surface emissions have a strong controlling effect on the variation in $\mathrm{CO}$ in the lower troposphere. This confinement of regional emissions in the lower atmosphere is likely due to subsidence prevailing over the area, as indicated by positive values of vertical velocity $700 \mathrm{mb}$. On the other hand, the vertical gradient of CO mixing ratios over the Fort McMurray area is small and there are relatively high values at high altitudes $(<500 \mathrm{hPa})$, which
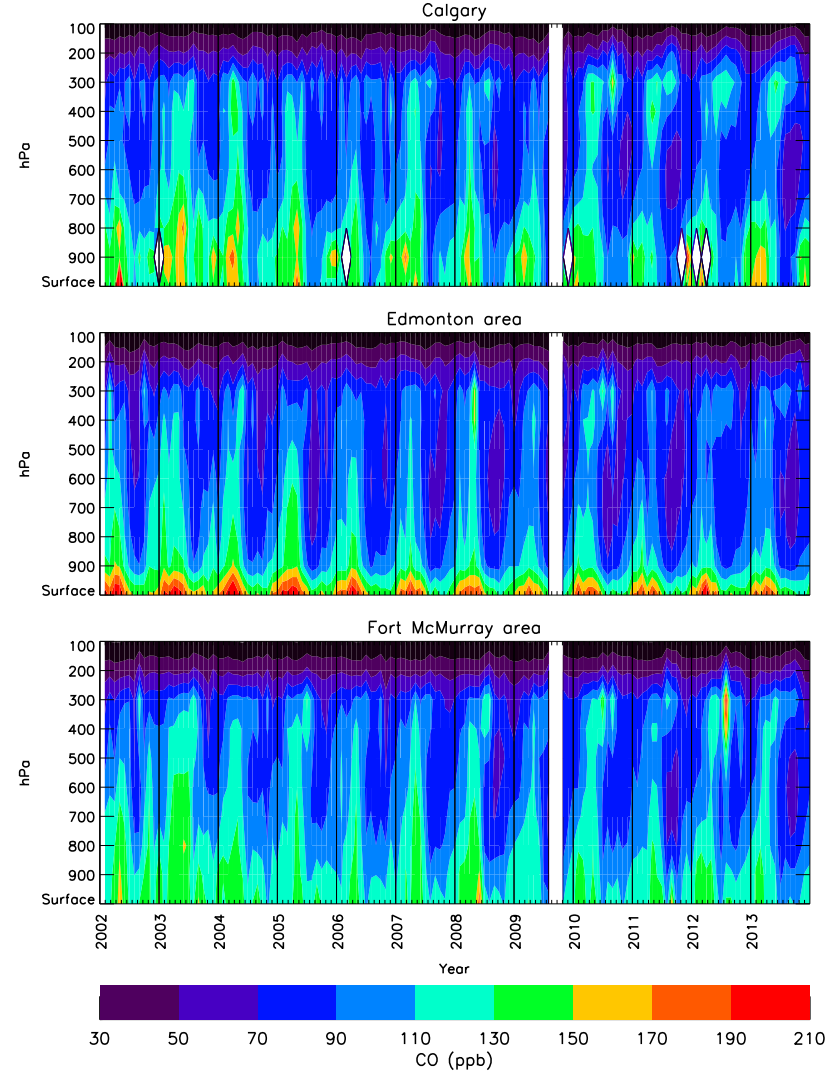

Figure 7. The 12-year interannual variation monthly averaged daytime MOPITT CO mixing ratios (ppb) as measured by MOPITT from January 2002 to December 2013 over the Calgary, Edmonton, and Fort McMurray areas.

may be the result of transported $\mathrm{CO}$ from biomass burning plumes. Furthermore, $\mathrm{CO}$ mixing ratios of the Edmonton and Calgary areas at lower altitudes are higher than the Fort McMurray area during the entire period. Additionally, the monthly average time series from 2002 to 2013 of CO mixing ratios over the Fort McMurray area displays a secondary peak in summer, while its magnitude varies from year to year. Summer CO episodes over the Fort McMurray area could be a signature of polluted air parcels coming from biomass burning emissions. Accordingly, the impact of forest fire on CO levels is examined in Sect. 3.4.

The interannual variation in CO total column is shown in Fig. 8. The mean for the whole series (12 years) is calculated and then subtracted from each monthly average to show interannual variation. To investigate whether there is a trend, a linear regression analysis was performed to fit the observations of the monthly CO total column for the Fort McMurray, Edmonton, and Calgary areas. A slightly decreasing trend is identified for all regions, with a declining percent (decreasing percent for the whole period) of $-1 \%$. The seasonal variation is evident each year with small interannual variability. The striking feature in 2012 is the presence of an air pollution 

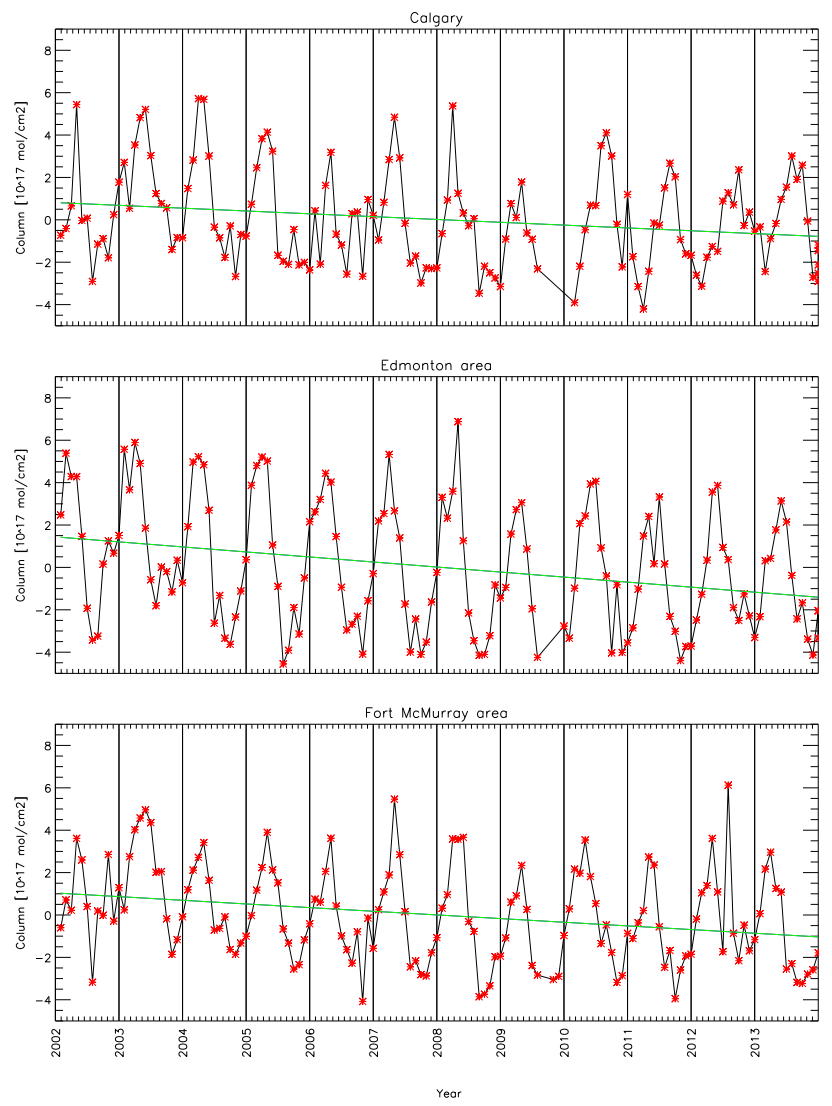

Figure 8. The 12-year interannual variations in monthly averaged daytime MOPITT CO total column measurements for the period January 2002 to December 2013 over the Calgary, Edmonton, and Fort McMurray areas.

episode in summer which is more prominent over the Fort McMurray area. CO total column variation in July over the Fort McMurray area shows a distinct peak among all maximums with a value of $2.6 \times 10^{18}$ molecules $\mathrm{cm}^{-2}$. Thus in Sect. 3.5 a case study of summer 2012 is analyzed.

\subsection{Comparison with MOZAIC/IAGOS aircraft CO profiles}

To verify MOPITT measurements, profiles of $\mathrm{CO}$ MOZAIC/IAGOS aircraft on descent to or ascent from Calgary airports are exploited for comparisons. The available aircraft data are between April 2009 and December 2011, with a total of 186 profiles. Because of MOPITT's temporal resolution of 2-3 days and the blockage of clouds, there are missing data in daily $\mathrm{CO}$ profiles, and hence only the matching MOPITT and aircraft profiles in time and location are utilized. For comparison, MOZAIC/IAGOS profiles are first interpolated to the pressure level of the corresponding MOPITT retrievals.

Since the MOPITT retrieval derives $\mathrm{CO}$ concentration profiles by combining its radiometric observations with a priori
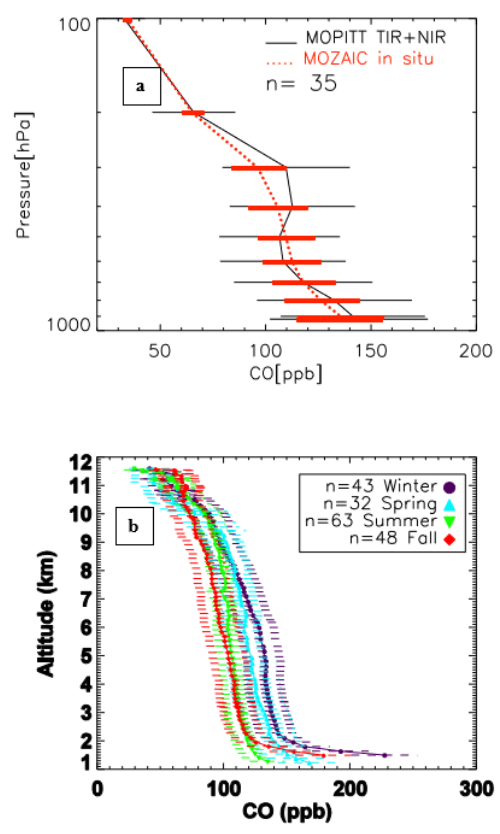

Figure 9. MOZAIC/IAGOS (AK) and the corresponding MOPITT $\mathrm{CO}$ profiles (a) and MOZAIC/IAGOS seasonal averages CO profile (b). Horizontal bars are standard errors.

estimates of the vertical profile of atmospheric $\mathrm{CO}$, the sensitivity of the retrievals to the actual concentration profiles must be considered when conducting quantitative comparisons to independent measurements (Emmons et al., 2004, 2007). The sensitivity of the MOPITT measurements to the true CO profile is represented by averaging kernels (Deeter et al., 2003). Accordingly, the interpolated aircraft profile is transformed by applying the averaging kernel and a priori profile associated with the corresponding MOPITT retrieval using Eq. (1) (Emmons et al., 2009). The transformed profiles $\left(x_{\text {ret }}\right)$ are denoted as MOZAIC/IAGOS (AK), and then they are averaged and plotted with corresponding MOPITTretrieved vertical profiles of $\mathrm{CO}$ as illustrated in Fig. 9a. The missing profile part above the highest altitude where MOZAIC/IAGOS measures is estimated from the MOPITT a priori profile:

$x_{\text {ret }}=\mathbf{A} x+(\mathbf{I}-\mathbf{A}) x_{\mathrm{a}}$,

where $x_{\mathrm{a}}$ is the a priori CO profile, $\mathbf{A}$ is the averaging kernel, and $x$ is the in situ CO profile.

Both aircraft and MOPITT measurements show that CO mixing ratios below $700 \mathrm{hPa}$ are higher than those above $700 \mathrm{hPa}$. The vertical distributions and gradients of aircraft and MOPITT $\mathrm{CO}$ mixing ratios are in good agreement with their averages values, which match fairly well within the standard deviations at all pressure levels. However, MOPITT averages generally have a positive bias in the upper troposphere, where the largest differences are seen below $400 \mathrm{mb}$. This result agrees with previous validation studies which 
Table 1. The boundaries of the study areas.

\begin{tabular}{lll}
\hline Name of study area & Latitude range & Longitude range \\
\hline Fort McMurray & 56.0 to $58.0^{\circ} \mathrm{N}$ & 112.0 to $110.0^{\circ} \mathrm{W}$ \\
Edmonton & 52.0 to $54.0^{\circ} \mathrm{N}$ & 114.0 to $112.0^{\circ} \mathrm{W}$ \\
Calgary & 50.0 to $52.0^{\circ} \mathrm{N}$ & 115.0 to $113.0^{\circ} \mathrm{W}$ \\
\hline
\end{tabular}

showed that there is a $14 \%$ high bias in MOPITT V5J data at $200 \mathrm{hPa}$ (Deeter et al., 2013). Nevertheless, the comparison demonstrates the potential of using multispectral MOPITT CO data in estimating surface air quality (Worden et al., 2010; Deeter et al., 2011). The seasonal profiles of the available MOZAIC/IAGOS data are computed and displayed in Fig. 9b. They illustrate higher concentrations in winter for all altitudes and minimum values in summer. Additionally, spring measurements exhibited relatively high mixing ratios above $\sim 2 \mathrm{~km}$. Thus the seasonal variation results are generally consistent with MOPITT results over Calgary city except that MOPITT shows the maximum in spring rather than winter. This discrepancy suggests that winter surface emissions are more confined in the boundary layer, which exacerbates the local surface pollution, resulting in high concentrations in winter. As MOPITT's sensitivity to CO is relatively low in the boundary layer (Deeter et al., 2007), surface emission may not be captured very well. Since the meteorological conditions in spring favor lofting the emissions up (warm air is of low density), the retrieved MOPITT signal in the midtroposphere can capture the enhanced $\mathrm{CO}$ where its sensitivity is better (Hyer et al., 2007). As a result the MOPITT data show the seasonal peak in spring rather than winter. This finding suggests the significant impact of transported emissions on $\mathrm{CO}$ levels. The surface seasonal variations in $\mathrm{CO}$ are further confirmed by analysis of ground-level measurements in the next section.

\subsection{Comparison with ground measurements}

In this section we consider analysis of surface $\mathrm{CO}$ recorded at nine monitoring stations as the in situ ground measurements are more sensitive to the boundary layer than the MOPITT $\mathrm{CO}$. The elevation, exact location, starting date, and the status are presented in Table 2. The selected stations sample various anthropogenic sources of CO: the Fort McMurray station is in an industrial town and the other stations are urban sites (Edmonton and Calgary). The monthly averaged time series of $\mathrm{CO}$ mixing ratio (ppb) at these stations are computed from 2000 to 2013 for comparison with MOPITT CO surface variability (Fig. 10). The availability of CASA data differs among the stations as shown in Table 1. The MOPITT data are centered at each location in a $1^{\circ}$ grid box.

The CO temporal evolutions from all stations reveal distinct annual and interannual variations with a significant declining trend. The trend is more recognizable over Edmonton
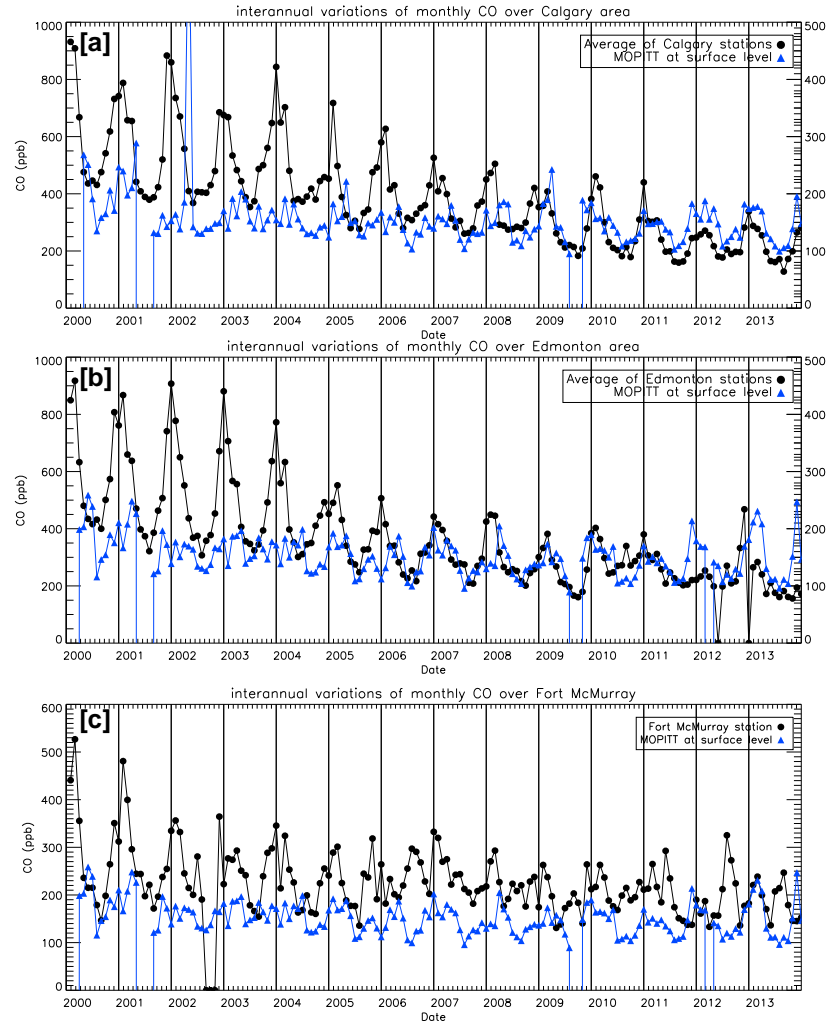

Figure 10. CASA CO in situ measurements (left axis) and MOPITT $\mathrm{CO}$ at surface level (right axis) at (a) Calgary, (b) Edmonton, and (c) Athabasca Valley.

and Calgary (Fig. 10a and b) than Fort McMurray (Fig. 10c); their maximum decline percent for the whole period is 4.4, 5.7 , and $0.6 \%$, respectively. Furthermore, the $\mathrm{CO}$ levels are much higher at the urban stations than the industrial one, with their maximum concentrations being about 1000 and $500 \mathrm{ppb}$, respectively. Comparing to MOPITT, the spatial and the temporal variations in surface $\mathrm{CO}$ mixing ratios also experienced higher values over the city of Edmonton than Fort McMurray. This finding is consistent with the results of Simpson et al. (2010), which showed relatively low emitted levels of CO throughout the mining operations (northern Fort McMurray area) even though the $\mathrm{CO}$ concentrations were $48 \%$ greater than the local background.

Additionally, it is apparent that the first 7 years $(2000$ 2006) have larger interannual variations than the next years (2006-2012), especially over the cities of Edmonton and Calgary. In other words, the decreasing rate in the last 6 years is not as large as the first years, which reflects the influence of improvements in $\mathrm{CO}$ emissions from vehicles (Alberta Environment, 2008). Moreover, for each city, there are discrepancies in the $\mathrm{CO}$ concentrations among different locations (not shown), where central and eastern Calgary and central and northwestern Edmonton stations exhibited the greatest values (not shown). This increase could be attributed to high 
Table 2. Location, elevation and starting date of selected CASA monitoring stations.

\begin{tabular}{lllrl}
\hline Name of the station & Longitude & Latitude & Elevation & Starting date \\
\hline Calgary Central 2 & 51.0470 & -114.0747 & 1051.0 & 1 Apr 2008 \\
Calgary Central & 51.0471 & -114.07315 & 1051.0 & 1 May 1979 \\
Calgary East & 51.0094 & -114.0253 & 1028.0 & 1 Aug 1974 \\
Calgary Northwest & 51.0792 & -114.1419 & 1106.0 & 1 Aug 1974 \\
Fort McMurray-Athabasca Valley & 56.7328 & -111.3903 & 260.0 & 1 Dec 1997 \\
Edmonton Central & 53.5444 & -113.4988 & 663.0 & 3 Dec 1976 \\
Edmonton East & 53.5481 & -113.3682 & 679.0 & 1 Oct 1972 \\
Edmonton Northwest & 53.5942 & -113.5400 & 679.0 & 12 Jul 1973 \\
Edmonton South & 53.5001 & -113.5261 & 681.0 & 21 Sep 2005 \\
\hline
\end{tabular}

traffic or industrial load at these locations, which implies the substantial impact of emission sources on ambient CO levels.

The seasonal cycle of $\mathrm{CO}$ is evident for all years at all stations where it is characterized by a maximum in winter (December and January) and a minimum in summer (Fig. 10). It is obvious that MOPITT CO surface data capture monthly variation as ground data, except at Fort McMurray 2006. However, the magnitude of the MOPITT surface values is less than ground data, which could be attributed to the fact that the MOPITT surface values are really the layer averages from the surface to the next level (e.g., $900 \mathrm{hPa}$ ), as well as to low MOPITT surface sensitivity. Seasonal variations at Fort McMurray (Athabasca Valley station) (Fig. 10c) are different for the whole study period, as there is a secondary visible peak in summer which is more pronounced in some years (e.g., 2012) than in others. Interestingly, the summer 2012 peak value exceeds the winter values of the same year, where monthly CO mixing ratios in July 2012 were more than $300 \mathrm{ppb}$. Although MOPITT temporal resolution is about 3 days (Liu et al., 2005), the same feature is detected by the MOPITT CO total column, where the monthly July average over Fort McMurray in 2012 exceeds that of May in the same year (as shown in Fig. 8). This implies the substantial impact of a non-industrial source, such as forest fires, on air quality. Consequently, it is essential to analyze the biomass burning over Alberta, where it is one of the major sources of CO (Morris et al., 2006).

\subsection{MODIS fire counts}

To assess the impact of forest fires on CO levels, the MODIS thermal anomaly product was analyzed for 13 years (20012013). GIS maps were used to display the spatial distributions of active fire points using ArcGIS software version 10.1. Figure 11 illustrates the seasonal variations in fire counts for the study period over Alberta. A significant number of fires occur during summer (June-August) in northern areas of Alberta, extending from west to east. In the spring (February-April), large forest fires are spatially clustered in the area north of Fort McMurray as well as in central Alberta. In the winter (December-February) and fall (September-
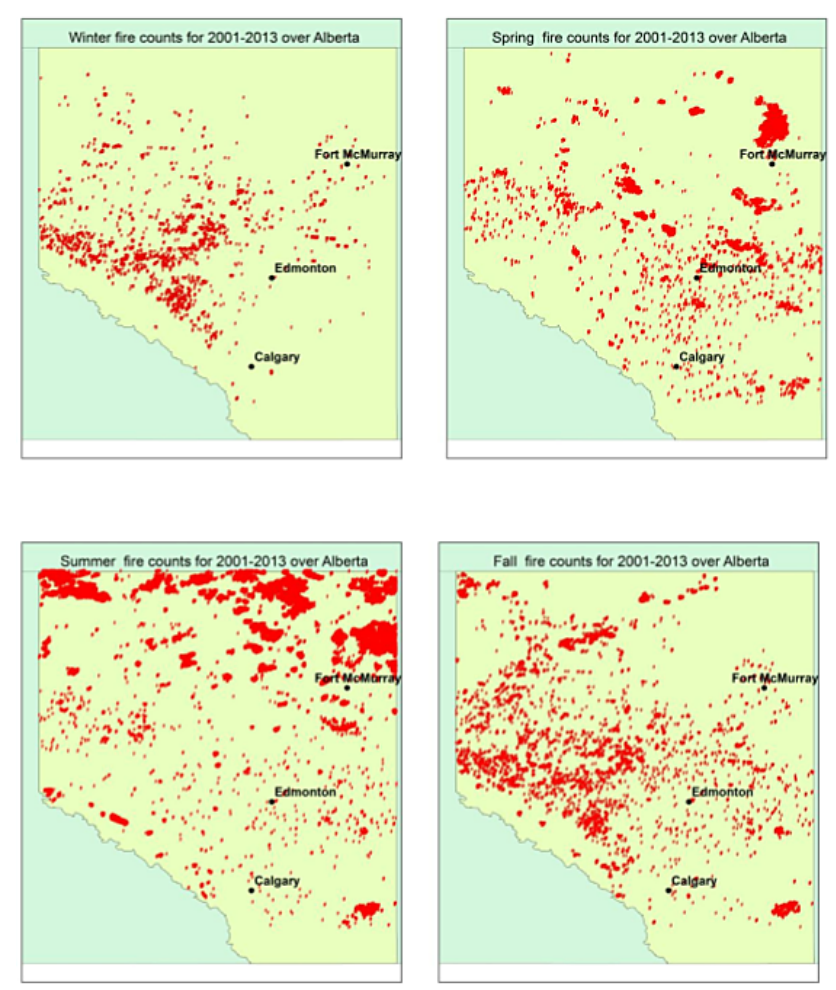

Figure 11. Seasonal variations in MODIS fire counts for the study period (2001-2013) over Alberta.

November) seasons, most of the fire locations are distributed in the western and northwestern areas of Alberta, especially in the fall season. Temporal analysis of fire count monthly averages for the entire period (2001-2013) demonstrates that July, June, and May comprise more than $65 \%$ of the total fire occurrence, with their relative frequencies being 35, 20, and $8 \%$, respectively (Fig. 12a). Thus, the period of MayJuly is recognized to be the main biomass burning season and is when the largest fires occur in northern Alberta. High pressure subsidence (a slow, sinking motion of high-level air occurring in high-pressure areas) and dry conditions were identified as the dominant conditions in this period of time 

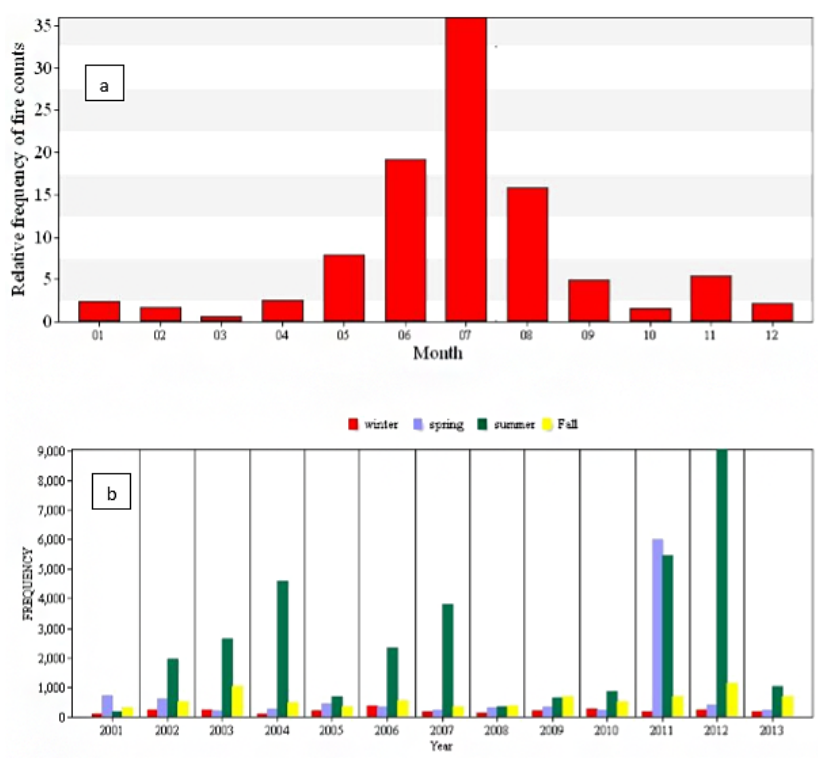

Figure 12. (a) Monthly variations in MODIS fire counts for the study period (2001-2013) over Alberta. (b) Interannual variations in seasonal fire frequency.

(May-July) which assist fires to spread and persist (Skinner et al., 2002; Soja et al., 2007). Interannual variations in seasonal fire frequency (Fig. 12b) indicate a large variability, with the total number of fire counts over Alberta increasing from 1959 in 2001 to 10608 in 2012. A very distinct increase in fire frequency is observed in summer each year, with the peak number being in 2012. Additionally, 2011 exhibited an elevated number of fires in spring and summer, when they exceeded 5500 fire counts for each. The overall pattern of fires is largely consistent with the seasonal and temporal variations in MOPITT CO values of northern Alberta as well as the ground-level in situ measurements at Fort McMurray station. Therefore, it is suggested that the high $\mathrm{CO}$ concentrations that emerge each summer in the area around Fort McMurray (northern Alberta) are mainly caused by the biomass burning of boreal forest fires. Earlier studies have pointed out the significance of biomass burning on air quality, which accounts for about $30 \%$ of the global total CO sources (Galanter et al., 2000).

To analyze in further detail the impact of fire emissions on $\mathrm{CO}$ levels and their transport, the variability of fire counts during July 2012 is examined as a case study. The daily time series of fire frequency in summer 2012 (not shown) illustrates a maximum number of fires on 10 and 11 July, when the fire counts exceeded 1200 and the fire radiative power (FRP) reached $9510 \mathrm{MW}$. Figure 13a and b display the MODIS Terra image combined with fire hotspots, indicated by red points, for 10 and 11 July 2012, respectively. It is clear that most of the red fire points are included in the smoke plumes or the head of the plumes, indicating that the plumes originated from those fires.
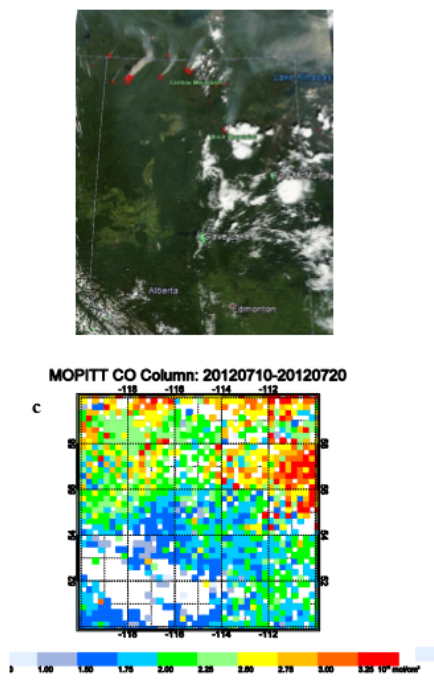

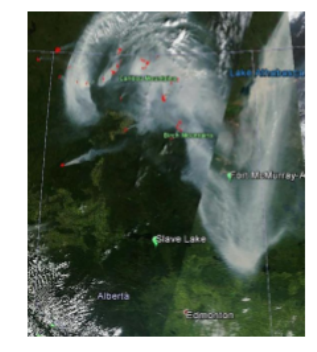

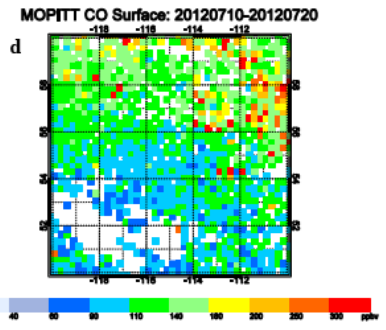

d

Figure 13. MODIS true image combined with fire points (red) on (a) 10 July 2012 and (b) 11 July 2012. (c) MOPITT CO total column from 10 to 20 July 2012 over Alberta and (d) MOPITT surface CO from 10 to 20 July 2012 over Alberta.

On 10 July 2012, the air mass was transported across Alberta toward the north, and then on 11 July it went from west to east, at which time it splits, with part of the air mass being transported south to the Fort McMurray area. To verify the transport pathway of smoke plumes, HYSPLIT forward trajectories analyses were performed for 10 July 2012 for a $48 \mathrm{~h}$ period (Fig. 14a). The starting conditions for these analyses included three fire point locations chosen from the MODIS fire data. The blue circles in the trajectories represent a time interval of $6 \mathrm{~h}$. Analyses were done for 500, 1000, and $2000 \mathrm{~m}$ heights, and it seems that the plumes stayed in the PBL during the first $12 \mathrm{~h}$, and then all of the plumes moved upward, reaching heights of up to $3000 \mathrm{~m}$. Moreover, the trajectories indicate that the air parcels traveled from northwest toward north and northeast, which coincides with MODIS smoke plume paths (Fig. 13a and b). Therefore, the HYSPLIT forward trajectory analysis provides evidence that some cities in Alberta could be affected by the fire emissions after a short time (24-48 h) depending on the starting plume height.

CO total column and surface composites for 10-20 July are displayed in Fig. 13c and d. The plume of $\mathrm{CO}$ expanded across the northeast of Alberta, where the CO total column and surface exceeded $3.25 \times 10^{18}$ molecules $\mathrm{cm}^{-2}$ and $300 \mathrm{ppb}$, respectively. Despite the limited vertical resolution of MOPITT measurements, a general enhancement of $\mathrm{CO}$ can be clearly seen for surface measurements, where the $\mathrm{CO}$ mixing ratio close to fires was as high as $300 \mathrm{ppbv}$, in comparison with a CO mixing ratio of $60-90 \mathrm{ppbv}$ in the background. However, the spatial pattern of total column and surface $\mathrm{CO}$ is not similar, with the former being more distinct in 

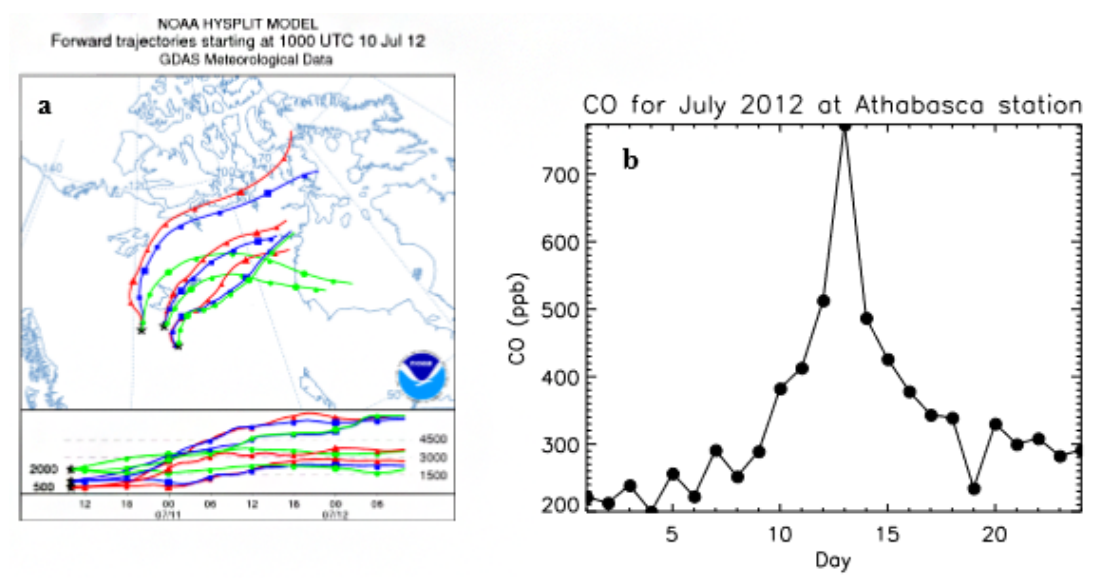

Figure 14. (a) $48 \mathrm{~h}$ HYSPLIT forward trajectory starting on 10 July 2012 and (b) daily CO at the Athabasca Valley station for July 2012.

the western area of Alberta than the latter, where more fires originated. The location of maximum surface CO is slightly shifted eastward from that of maximum fire counts. This is likely due to the transport of $\mathrm{CO}$ with the prevailing westerly winds.

Although most of the fires originated in the northwestern area of Alberta (for summer 2012), MOPITT images revealed intense $\mathrm{CO}$ plumes in the east which match remarkably well with MODIS and HYSPLIT trajectories. This implies the substantial influence of long-range transport on $\mathrm{CO}$ levels, as its long lifetime allows plumes with elevated $\mathrm{CO}$ to travel long distances, affecting air quality downstream of the point source emissions. Zhao et al. (2007) indicated that a high-CO episode in a remote area can result from long-range transport from active biomass burning and biofuel burning areas rather than local air pollution.

A daily time series of in situ measurements at Athabasca Valley station for July 2012 reveals (Fig. 14b) elevated CO concentrations during the intense forest fire period. Although the total number of hotspots peaked on 10 July, the enhancement of $\mathrm{CO}$ was found to reach the maximum value later on 12 July, when it exceeded $700 \mathrm{ppb}$. This further confirms the important effect of transport on atmospheric $\mathrm{CO}$ values.

Generally, the in situ measurements are in good agreement with MOPITT data; however the magnitude of in situ measurements is higher than surface MOPITT data. The reason could be the larger spatial footprint of MOPITT data $(22 \mathrm{~km} \times 22 \mathrm{~km})$, as opposed to in situ measurements which represent point data. In addition, since MOPITT is not very sensitive to the $\mathrm{CO}$ in the boundary layer, it is possible that the sharp surface features are masked and hence the retrieved $\mathrm{CO}$ values in the boundary layer are lower than reality during biomass burning emissions.

\section{Summary and conclusions}

This study demonstrated the potential use of MOPITT $\mathrm{CO}$ measurements to better understand and quantify $\mathrm{CO}$ sources over Alberta. MOPITT-based climatology and interannual variations were analyzed for 12 years (2002-2013) on spatial and temporal scales. The MOPITT V5 multispectral product, which uses both near-infrared and thermalinfrared radiances, was used for the $\mathrm{CO}$ retrieval. Available MOZAIC/IAGOS aircraft CO profiles over Calgary were used to validate MOPITT CO data. Additionally, CO ground measurements were compared to satellite data. The MODIS thermal anomaly product from 2001 to 2013 was employed to investigate the effect of seasonal variations in fires on climatological and interannual CO levels. To further recognize the fate and the impact of biomass burning emissions on air quality, forest fires on a severe day have been analyzed as a case study.

Seasonal climatological maps for CO total columns indicated conspicuous spatial variations in all seasons except winter, when the CO spatial variations are less prominent. High CO loadings are observed to extend from the northeast to northwest of Alberta, with highest values (2.5$2.75 \times 10^{18}$ molecules $\mathrm{cm}^{-2}$ ) in spring. The $\mathrm{CO}$ mixing ratios at the surface level in the winter and spring seasons exhibited dissimilar spatial distribution patterns in which the enhancements are detected in the southeast of Alberta (east of Edmonton city) rather than the north, with a mixing ratio range of 250-300 ppb. Analyzing spatial distributions of omega at the $850 \mathrm{mb}$ pressure level for four seasons implied that conditions in northeastern Alberta are more favorable for uplofting, while subsidence of $\mathrm{CO}$ emissions is more likely in the south. Thus, meteorological parameters may affect the CO spatial distribution profile, where the CO total columns show remarkable enhancements in the north and the surface $\mathrm{CO}$ experiences high values in the southern area. 
The time-altitude climatology of the $\mathrm{CO}$ profiles as well as the interannual variability is investigated for the Fort McMurray, Edmonton, and Calgary regions to compare the impact of various sources on CO loading. Monthly variations over the Edmonton region are consistent with the general seasonal cycle of $\mathrm{CO}$ in the Northern Hemisphere (Edwards et al., 2004), which exhibits significant enhancement in winter and spring and minimum mixing ratios in summer. The typical seasonal $\mathrm{CO}$ variations over the Fort McMurray area are less prominent, where there is an obvious increase in $\mathrm{CO}$ in summer. The same seasonal patterns are detected at various surface monitoring stations; however the magnitudes of in situ measurements are higher. Interannual variations in satellite data display a slightly decreasing trend for both regions, while the decline trend is more evident from ground observations, especially in the Edmonton and Calgary regions. These discrepancies (between satellite and ground data) may be explained by larger MOPITT spatial resolution and its lower sensitivity to the surface $\mathrm{CO}$.

MOPITT CO profiles are validated by comparing them to the available MOZAIC/IAGOS aircraft profiles after applying the averaging kernel (Emmons et al., 2009). Both vertical distributions showed good agreement within the standard deviations at all pressure levels.

Time-altitude CO profile measurements over the Edmonton and Calgary regions exhibited relatively elevated $\mathrm{CO}$ values in the lower troposphere than the corresponding values over the Fort McMurray area. However, the total column CO values are similar. This striking feature suggests that the $\mathrm{Ed}-$ monton and Calgary regions may be blanketed by regional pollution, while the Fort McMurray area (northern Alberta) may be influenced by $\mathrm{CO}$ plumes transported either vertically or horizontally, which could be from industry and/or the biomass burning. Temporal analysis of fire frequency showed that the main biomass burning season is from May to July, when the largest fires are clustered spatially in northern and central Alberta. The spatial distributions of fires remarkably match the spatial distributions of MOPITT CO total column in spring and summer. Additionally, there is consistency between the time evolutions of high-CO episodes that are monitored by satellite and ground measurements in the Fort McMurray area and the fire frequency peak time. This finding implies that biomass burning and its transport have interesting consequences for the tropospheric $\mathrm{CO}$ distribution in northern Alberta, given the complex meteorology that prevails in this area.

Since 2012 depicted high fire frequency, 10 July 2012 was selected for analysis of the biomass burning smoke plumes. Daily time series of ground measurements in Fort McMurray revealed elevated CO concentrations on 12 July ( $>700 \mathrm{ppb}$ ), which is 2 days after peak fire frequency (10 July). Furthermore, a MOPITT composite image for the fire severity period (10-20 July) displayed a more intense CO plume in the eastern rather than western area, where most of the fires originated. This result reflects the significant influence of long- range transport of biomass burning emissions on $\mathrm{CO}$ levels, which is further confirmed by MODIS smoke plume images and HYSPLIT forward trajectories.

Acknowledgements. We acknowledge the use of FIRMS data and imagery from the Land Atmosphere Near-real time Capability for EOS (LANCE) system operated by the NASA/GSFC/Earth Science Data and Information System (ESDIS) with funding provided by NASA/HQ. We also acknowledge the NOAA Air Resources Laboratory (ARL) for the provision of the HYSPLIT transport model used in this publication. We are grateful to the satellite product developers of MOPITT CO for freely sharing the data through National Center for Atmospheric Research (NCAR) portals. The NCAR MOPITT project is supported by the National Aeronautics and Space Administration (NASA) Earth Observing System (EOS) Program. The National Center for Atmospheric Research (NCAR) is sponsored by the National Science Foundation. The authors also acknowledge the Canadian Space Agency (CSA), who provided MOPITT instrument data. Finally, we are very grateful to Alberta Environment and the MITACS Elevate program for funding this research.

Edited by: M. Maione

\section{References}

Alberta Environment: Alberta Air emissions trends and projections, available at: http://environment.gov.ab.ca/info/library/7964.pdf (last access: April 2015), 2008.

Alberta Environment: Oil sands, the resources, available at: http://www.oilsands.alberta.ca/FactSheets/Resource_FSht_ June_2012_Online.pdf (last access: April 2015), 2012.

Amiro, B. D., Todd, J. B., Wotton, B. M., Logan, K. A., Flannigan, M. D., Stocks, B. J., Mason, J. A., Martell, D. L., and Hirsch, K. G.: Direct carbon emissions from Canadian forest fires, 19591999, Can. J. Forest. Res., 31, 512-525, 2001.

Bytnerowicz, A., Fraczek, W., Schilling, S., and Alexander, D.: Spatial and temporal distribution of ambient nitric acid and ammonia in the Athabasca Oil Sands Region, Alberta, J. Limnol., 69, 11$21,2010$.

CAPP (Canadian Association of Petroleum Producers): Crude oil forecast, marketing and pipelines, available at: http: //www.strategywest.com/downloads/CAPP201206.pdf (last access: April 2015), 2012.

Colarco, P. R., Schoeberl, M. R., Doddridge, B. G., Marufu, L. T., Torres, O., and Welton, E. J.: Transport of smoke from Canadian forest fires to the surface near Washington, D.C.: Injection height, entrainment and optical properties, J. Geophys. Res., 109, D06203, doi:10.1029/2003JD004248, 2004.

Cullen, R. M. and Marshall, S. J.: Mesoscale temperature patterns in the Rocky Mountains and foothills region of Southern Alberta, Atmos. Ocean., 49, 189-205, doi:10.1080/07055900.2011.592130, 2011.

Daniel, J. S. and Solomon, S.: On the climate forcing of carbon monoxide, J. Geophys. Res., 103, 13249-13260, 1998.

Deeter, M. N., Emmons, L. K., Francis, G. L., Edwards, D. P., Gille, J. C., Warner, J. X., Khattatov, B., Ziskin, D., Lamarque, J. F., 
Ho, S. P., Yudin, V., Attie, J. L., Packman, D., Chen, J., Mao, D., and Drummond, J. R.: Operational carbon monoxide retrieval algorithm and selected results for the MOPITT instrument, J. Geophys. Res., 108, 4399, doi:10.1029/2002JD003186, 2003.

Deeter, M. N., Edwards, D. P., Gille, J. C., and Drummond, J. R.: Sensitivity of MOPITT observations to carbon monoxide in the lower troposphere. J. Geophys. Res., 112, D24306, doi:10.1029/2007JD008929, 2007.

Deeter, M. N., Worden, H. M., Edwards, D. P., Gille, J. C., Mao, D., and Drummond, J. R.: MOPITT multispectral CO retrievals: Origins and effects of geophysical radiance errors, J. Geophys. Res., 116, D15303, doi:10.1029/2011JD015703, 2011.

Deeter, M. N., Worden, H. M., Edwards, D. P., Gille, J. C., and Andrews, A. E.: Evaluation of MOPITT retrievals of lowertropospheric carbon monoxide over the United States, J. Geophys. Res., 117, D13306, doi:10.1029/2012JD017553, 2012.

Deeter, M. N., Martínez-Alonso, S., Edwards, D. P., Emmons, L. K., Gille, J. C., Worden, H. M., Pittman, J. V., Daube, B. C., and Wofsy, S. C.: Validation of MOPITT Version 5 thermalinfrared, near-infrared, and multispectral carbon monoxide profile retrievals for 2000-2011, J. Geophys. Res., 118, 6710-6725, doi:10.1002/jgrd.50272, 2013.

Draxler, R. R. and Hess, G. D.: An overview of the HYSPLIT_4 modelling system for trajectories, dispersion and deposition, Aust. Meteorol. Mag., 47, 295-308, 1998.

Draxler, R. R. and Rolph, G. D.: HYSPLIT (HYbrid Single-Particle Lagrangian Integrated Trajectory) Model access via NOAA ARL READY Website, available at: http://ready.arl.noaa.gov/ HYSPLIT.php (last access: 9 April 2015), NOAA Air Resources Laboratory, Silver Spring, MD, 2015.

Drummond, J. R.: Measurements of Pollution in the Troposphere (MOPITT), in: The Use of EOS for Studies of Atmospheric Physics, edited by: Gille, J. C. and Visconti, G., Elsevier Science Publications, New York, 77-101, 1992.

Duncan, B. N., Logan, J. A., Bey, I., Megretskaia, I. A., Yantosca, R. M., Novelli, P. C., Jones, N. B., and Rinsland, C. P.: Global budget of CO, 1988-1997: Source estimates and validation with a global model, J. Geophys. Res., 112, D22301, doi:10.1029/2007JD008459, 2007.

EC (Environment Canada): Total air pollutants emissions for Alberta, available at: http://www.ec.gc.ca/inrp-npri/default. asp?lang=en\&n=0EC58C98\#Emission_Summaries (last access: April 2015), 2012.

Edwards, D. P., Emmons, L. K., Hauglustaine, D. A., Chu, D. A., Gille, J. C., Kaufman, Y. J., Pétron, G., Yurganov, L. N., Giglio, L., Deeter, M. N., Yudin, V., Ziskin, D. C., Warner, J., Lamarque, J.-F., Francis, G. L., Ho, S. P., Mao, D., Chen, J., Grechko, E. I., and Drummond, J. R.: Observations of carbon monoxide and aerosols from the Terra satellite: Northern Hemisphere variability, J. Geophys. Res., 109, D24202, doi:10.1029/2004JD004727, 2004.

Emmons, L. K., Deeter, M. N., Gille, J. C., Edwards, D. P., Attié, J.-L., Warner, J., Ziskin, D., Francis, G., Khattatov, B., Yudin, V., Lamarque, J.-F, Ho, S.-P, Mao, D., Chen, J. S., Drummond, J., Novelli, P., Sachse, G., Coffey, M. T., Hannigan, J. W., Gerbig, C., Kawakami, S., Kondo, Y., Takegawa, N., Schlager, H., Baehr, J., and Zierei, H.: Validation of Measurements of Pollution in the Troposphere (MOPITT) CO retrievals with aircraft in situ profiles, J. Geophys. Res., 109, D03309, doi:10.1029/2003JD004101, 2004.

Emmons, L. K., Pfister, G. G., Edwards, D. P., Gille, J. C., Sachse, G., Blake, D., Wofsy, S., Gerbig, C., Matross, D., and Nédélec, P.: Measurements of Pollution in the Troposphere (MOPITT) validation exercises during summer 2004 field campaigns over North America, J. Geophys. Res., 112, D12S02, doi:10.1029/2006JD007833, 2007.

Emmons, L. K., Edwards, D. P., Deeter, M. N., Gille, J. C., Campos, T., N'edélec, P., Novelli, P., and Sachse, G.: Measurements of Pollution In The Troposphere (MOPITT) validation through 2006, Atmos. Chem. Phys., 9, 1795-1803, doi:10.5194/acp-91795-2009, 2009.

Flannigan, M. D., Logan, K. A., Amiro, B. D., Skinner, W. R., and Stocks, B. J.: Future area burned in Canada, Climatic Change, 72, 1-16, 2005.

Galanter, M., Levy II, H., and Carmichael, G. R.: Impacts of biomass burning on tropospheric $\mathrm{CO}, \mathrm{NO}_{x}$, and $\mathrm{O}_{3}$, J. Geophys. Res., 105, 6633-6653, 2000.

Giglio, L.: MODIS Collection 5 Active Fire Product User's Guide, Version 2.4. SSAI, Lanham, Maryland, available at: http://www.fao.org/fileadmin/templates/gfims/docs/MODIS_ Fire_Users_Guide_2.4.pdf (last access: April 2015), 2010.

Giglio, L., Descloitres, J., Justice, C. O., and Kaufman, Y. J.: An enhanced contextual fire detection algorithm for MODIS, Remote Sens. Environ., 87, 273-282, 2003.

Gillett, N. P., Weaver, A. J., Zwiers, F. W., and Flannigan, M. D.: Detecting the effect of climate change on Canadian forest fires, Geophys. Res. Lett., 31, L18211, doi:10.1029/2004GL020876, 2004.

Girardin, M. P.: Interannual to decadal changes in area burned in Canada from 1781 to 1982 and the relationship to Northern Hemisphere land temperatures, Global Ecol. Biogeogr., 16, 557566, 2007.

Howell, S. G., Clarke, A. D., Freitag, S., McNaughton, C. S., Kapustin, V., Brekovskikh, V., Jimenez, J.-L., and Cubison, M. J.: An airborne assessment of atmospheric particulate emissions from the processing of Athabasca oil sands, Atmos. Chem. Phys., 14, 5073-5087, doi:10.5194/acp-14-5073-2014, 2014.

Hyer, E. J., Allen, D. J., and Kasischke, E. S.: Examining injection properties of boreal forest fires using surface and satellite measurements of CO transport, J. Geophys. Res., 112, D18307, doi:10.1029/2006JD008232, 2007.

Jacob, D. J., Crawford, J. H., Maring, H., Clarke, A. D., Dibb, J. E., Emmons, L. K., Ferrare, R. A., Hostetler, C. A., Russell, P. B., Singh, H. B., Thompson, A. M., Shaw, G. E., McCauley, E., Pederson, J. R., and Fisher, J. A.: The Arctic Research of the Composition of the Troposphere from Aircraft and Satellites (ARCTAS) mission: design, execution, and first results, Atmos. Chem. Phys., 10, 5191-5212, doi:10.5194/acp-10-5191-2010, 2010.

Jiang, J. H., Livesey, N. J., Su, H., Neary, L., McConnell, J. C., and Richards, N. A. D.: Connecting surface emissions, convective uplifting, and long-range transport of carbon monoxide in the upper troposphere: New observations from the Aura Microwave Limb Sounder, Geophys. Res. Lett., 34, L18812, doi:10.1029/2007GL030638, 2007

Jiang, Z., Jones, D. B. A., Worden, H. M., Deeter, M. N., Henze, D. K., Worden, J., Bowman, K. W., Brenninkmeijer, C. A. M., and Schuck, T. J.: Impact of model errors in convective transport 
on CO source estimates inferred from MOPITT CO retrievals, J. Geophys. Res., 118, 2073-2083, doi:10.1002/jgrd.50216, 2013.

Kalnay, E., Kanamitsu, M., Kistler, R., Collins, W., Deaven, D., Gandin, L., Iredell, M., Saha, S., White, G., Woollen, J., Zhu, Y., Leetmaa, A., Reynolds, R., Chelliah, M., Ebisuzaki, W., Higgins, W., Janowiak, J., Mo, K.C., Ropelewski, C., Wang, J., Jenne, R., and Joseph, D.: The NCEP/NCAR 40-Year Reanalysis Project, B. Am. Meteorol. Soc., 77, 437-471, 1996.

Kaufman, Y. J., Herring, D. D., Ranson, K. J., and Collatz, G. J.: Earth Observing System AM1 mission to Earth, IEEE T. Geosci. Remote., 36, 1045-1055, 1998a.

Kaufman, Y. J., Justice, C., Flynn, L., Kendall, J., Prin, E., Giglio, L., Ward, D. E., Menzel, P., and Setzer, A.: Potential global fire monitoring from EOS - MODIS, J. Geophys. Res., 103, 3221532338, doi:10.1029/98JD01644, 1998b

Kean, S.: Eco-alchemy in Alberta, Science, 326, 1052-1055, 2009.

Liu, J., Drummond, J. R., Li, Q., and Gille, J. C.: Satellite mapping of $\mathrm{CO}$ emission from forest fires in Northwest America using MOPITT measurements, Remote Sens. Environ., 95, 502-516, 2005.

Liu, J., Logan, J. A., Jones, D. B. A., Livesey, N. J., Megretskaia, I., Carouge, C., and Nedelec, P.: Analysis of CO in the tropical troposphere using Aura satellite data and the GEOS-Chem model: insights into transport characteristics of the GEOS meteorological products, Atmos. Chem. Phys., 10, 12207-12232, doi:10.5194/acp-10-12207-2010, 2010.

Livesey, N. J., Logan, J. A., Santee, M. L., Waters, J. W., Doherty, R. M., Read, W. G., Froidevaux, L., and Jiang, J. H.: Interrelated variations of $\mathrm{O}_{3}, \mathrm{CO}$ and deep convection in the tropical/subtropical upper troposphere observed by the Aura Microwave Limb Sounder (MLS) during 2004-2011, Atmos. Chem. Phys., 13, 579-598, doi:10.5194/acp-13-579-2013, 2013.

Marenco, A., Thouret, V., Nedéelec, P., Smit, H., Helten, M., Kley, D., Karcher, F., Simon, P., Law, K., Pyle, J., Poschmann, G., Von Wrede, R., Hume, C., and Cook, T.: Measurement of ozone and water vapor by Airbus in-service aircraft: The MOZAIC airborne program, an overview, J. Geophys. Res., 103, 631-642, 1998.

Marlon, J. R., Bartlein, P. J., Carcaillet, C., Gavin, D. G., Harrison, S. P., Higuera, P. E., Joos, F., Power, M. J., and Prentice, I. C.: Climate and human influences on global biomass burning over the past two millennia, Nat. Geosci., 1, 69-702, 2008.

Martin, R. V.: Satellite remote sensing of surface air quality, Atmos. Environ., 42, 7823-7843, 2008.

Masuoka, E., Fleig, A., Wolfe, R. W., and Patt, F.: Key characteristics of the MODIS data products. IEEE T. Geosci. Remote, 36, 1313-1323, doi:10.1109/36.701081, 1998.

McLinden, C. A., Fioletov, V., Boersma, K. F., Krotkov, N., Sioris, C. E., Veefkind, J. P., and Yang, K.: Air quality over the Canadian oil sands: A first assessment using satellite observations, Geophys. Res. Lett., 39, L04804, doi:10.1029/2011GL050273, 2012.

Morris, G. A., Hersey, S., Thompson, A. M., Pawson, S., Nielsen, J. E., Colarco, P. R., McMillan, W. W., Stohl, A., Turquety, S., Warner, J., Johnson, B. J., Kucsera, T. L., Larko, D. E., Oltmans, S. J., and Witte, J. C.: Alaskan and Canadian forest fires exacerbate ozone pollution over Houston, Texas, on 19 and 20 July 2004, J. Geophys. Res., 111, D24S03, doi:10.1029/2006JD007090, 2006.
NEB (National Energy Board): ARCHIVED - Canada's Oil Sands - Opportunities and Challenges to 2015: An Update, available at: https://www.neb-one.gc.ca/nrg/sttstc/ crdlndptrlmprdct/rprt/archive/pprtntsndchllngs20152006/ qapprtntsndchllngs20152006-eng.html, last access: April 2015.

Nedelec, P., Cammas, J.-P., Thouret, V., Athier, G., Cousin, J.-M., Legrand, C., Abonnel, C., Lecoeur, F., Cayez, G., and Marizy, C.: An improved infrared carbon monoxide analyser for routine measurements aboard commercial Airbus aircraft: technical validation and first scientific results of the MOZAIC III programme, Atmos. Chem. Phys., 3, 1551-1564, doi:10.5194/acp-3-15512003, 2003.

Novelli, P. C., Masarie, K. A., and Lang, P. M.: Distributions and recent changes in carbon monoxide in the lower troposphere, J. Geophys. Res., 103, 19015-19033, 1998.

Pétron, G., Granier, C., Khattotov, B., Yudin, V., Lamarque, J.-F., Emmons, L., Gille J., and Edwards, D. P.: Monthly CO surface sources inventory based on the 2000-2001 MOPITT satellite data, Geophys. Res. Lett., 31, L21107, doi:10.1029/2004GL020560, 2004.

Pfister, G. G., Emmons, L. K., Hess, P. G., Honrath, R., Lamarque, J.-F., Val Martin, M., Owen, R. C., Avery, M. A., Browell, E. V., Holloway, J. S., Nedelec, P., Purvis, R., Ryerson, T. B., Sachse, G. W., and Schlager, H.: Ozone production from the 2004 North American boreal fires, J. Geophys. Res., 111, D24S07, doi:10.1029/2006JD007695, 2006.

Preston, C. M. and Schmidt, M. W. I.: Black (pyrogenic) carbon: a synthesis of current knowledge and uncertainties with special consideration of boreal regions, Biogeosciences, 3, 397-420, doi:10.5194/bg-3-397-2006, 2006.

Ridley, B. A., Madronich, S., Chatfield, R. B., Walega, J. G., Shetter, R. E., Carroll, M. A., and Montzka, D. D.: Measurements and model simulations of the photostationary state during the Mauna Loa Observatory Photochemistry Experiment: Ozone production and loss rates, J. Geophys. Res., 97, 10375-10388, 1992.

Rolph, G. D.: Real-time Environmental Applications and Display sYstem (READY) Website, available at: http://ready.arl.noaa.gov (last access: 9 April 2015), NOAA Air Resources Laboratory, Silver Spring, MD, 2015.

Siddique, T., Fedorak, P. M., and Foght, J. M.: Biodegradation of short-chain n-alkanes in oil sands tailings under methanogenic conditions, Environ. Sci. Technol., 40, 5459-5464, 2006.

Siddique, T., Fedorak, P. M., MacKinnon, M. D., and Foght, J. M.: Metabolism of BTEX and naphtha compounds to methane in oil sands tailings, Environ. Sci. Technol., 41, 2350-2356, 2007.

Simpson, I. J., Blake, N. J., Barletta, B., Diskin, G. S., Fuelberg, H. E., Gorham, K., Huey, L. G., Meinardi, S., Rowland, F. S., Vay, S. A., Weinheimer, A. J., Yang, M., and Blake, D. R.: Characterization of trace gases measured over Alberta oil sands mining operations: 76 speciated $\mathrm{C}_{2}-\mathrm{C}_{10}$ volatile organic compounds (VOCs), $\mathrm{CO}_{2}, \mathrm{CH}_{4}, \mathrm{CO}, \mathrm{NO}, \mathrm{NO}_{2}, \mathrm{NO}_{y}, \mathrm{O}_{3}$ and $\mathrm{SO}_{2}$, Atmos. Chem. Phys., 10, 11931-11954, doi:10.5194/acp-10-11931-2010, 2010.

Simpson, I. J., Akagi, S. K., Barletta, B., Blake, N. J., Choi, Y., Diskin, G. S., Fried, A., Fuelberg, H. E., Meinardi, S., Rowland, F. S., Vay, S. A., Weinheimer, A. J., Wennberg, P. O., Wiebring, P., Wisthaler, A., Yang, M., Yokelson, R. J., and Blake, D. R.: Boreal forest fire emissions in fresh Canadian smoke plumes: $\mathrm{C}_{1}-\mathrm{C}_{10}$ volatile organic compounds (VOCs), $\mathrm{CO}_{2}, \mathrm{CO}, \mathrm{NO}_{2}$ 
NO, $\mathrm{HCN}$ and $\mathrm{CH}_{3} \mathrm{CN}$, Atmos. Chem. Phys., 11, 6445-6463, doi:10.5194/acp-11-6445-2011, 2011.

Skinner, W. R., Flannigan, M. D., Stocks, B. J., Martell, D. M., Wotton, B. M., Todd, J. B., Mason, J. A., Logan, K. A., and Bosch, E. M.: A $500 \mathrm{mb}$ synoptic wildland fire climatology from large Canadian forest fires, 1959-1996, Theor. Appl. Climatol., 71, 157-169, 2002.

Soja, A. J., Tchebakova, N. M., French, N. H. F., Flannigan, M. D., Shugart, H. H., Stocks, B. J., Sukhinin, A. I., Varfenova, E. I., Chapin, F. S., and Stackhouse Jr., P. W.: Climate induced boreal forest change: predictions versus current observations, Global Planet Change, 56, 274-296, 2007.

Stocks, B. J., Fosberg, M. A., Lynham, T. J., Mearns, L., Wotton, B. M., Yang, Q., Jin, J. Z., Lawrence, K., Hartley, G. R., Mason, J. A., and McKenney, D. W.: Climate change and forest fire potential in Russian and Canadian boreal forests, Climate Change, 38, 1-13, doi:10.1023/A:1005306001055, 1998.

Strausz, O., Jha, K. N., and Montgomery, D. S.: Chemical composition of gases in Athabasca bitumen and in low-temperature thermolysis of oil sand, asphaltene and maltene, Fuel, 56, 114-120, doi:10.1016/0016-2361(77)90128-4, 1977.
Thompson, A. M.: The oxidizing capacity of the Earth's atmosphere: Probable past and future changes, Science, 256, 1157$1165,1992$.

Timoney, K. and Lee, P.: Does the Alberta tar sands industry pollute? The scientific evidence, The Open Conservation Biology Journal, 3, 65-81, 2009.

WBEA (Wood Buffalo Environmental Association): available at: http://www.wbea.org/, last access: April 2015.

Worden, H. M., Deeter, M. N., Edwards, D. P., Gille, J. C., Drummond, J. R., and Nedelec, P. P.: Observations of near-surface carbon monoxide from space using MOPITT multispectral retrievals, J. Geophys. Res., 115, D18314, doi:10.1029/2010JD014242, 2010.

Zhao, C., Peng, L., Tie, X. X., Lin, Y., Li, C., Zheng, X., and Fang, Y.: A high $\mathrm{CO}$ episode of long-range transport detected by MOPITT, Water Air Soil Poll., 178, 207-216, doi:10.1007/s11270006-9191-1, 2007. 